\title{
SURFATM-NH3: a model combining the surface energy balance and bi-directional exchanges of ammonia applied at the field scale
}

\author{
E. Personne ${ }^{1}$, B. Loubet ${ }^{1}$, B. Herrmann ${ }^{2}$, M. Mattsson ${ }^{3}$, J. K. Schjoerring ${ }^{3}$, E. Nemitz ${ }^{4}$, M. A. Sutton ${ }^{4}$, and P. Cellier ${ }^{1}$ \\ ${ }^{1}$ UMR Environment et Grandes Cultures/INRA - AgroParisTech, 78850 Thiverval Grignon, France \\ ${ }^{2}$ Agroscope Reckenholz-Tänikon Research Station ART, Reckenholzstrasse 191, 8046 Zürich, Switzerland \\ ${ }^{3}$ Plant and Soil Science Laboratory, University of Copenhagen, Faculty of Life Sciences, Thorvaldsensvej 40, \\ 1871 Frederiksberg C, Copenhagen, Denmark \\ ${ }^{4}$ Centre for Ecology and Hydrology, Edinburgh Research Station, Bush Estate, Penicuik, Midlothian, EH26 0QB, UK
}

Received: 30 September 2008 - Published in Biogeosciences Discuss.: 6 January 2009

Revised: 23 June 2009 - Accepted: 7 July 2009 - Published: 4 August 2009

\begin{abstract}
A new biophysical model SURFATM-NH3, simulating the ammonia $\left(\mathrm{NH}_{3}\right)$ exchange between terrestrial ecosystems and the atmosphere is presented. SURFATMNH3 consists of two coupled models: (i) an energy budget model and (ii) a pollutant exchange model, which distinguish the soil and plant exchange processes. The model describes the exchanges in terms of adsorption to leaf cuticles and bi-directional transport through leaf stomata and soil. The results of the model are compared with the flux measurements over grassland during the GRAMINAE Integrated Experiment at Braunschweig, Germany. The dataset of GRAMINAE allows the model to be tested in various meteorological and agronomic conditions: prior to cutting, after cutting and then after the application of mineral fertilizer. The whole comparison shows close agreement between model and measurements for energy budget and ammonia fluxes. The major controls on the ground and plant emission potential are the physicochemical parameters for liquid-gas exchanges which are integrated in the compensation points for live leaves, litter and the soil surface. Modelled fluxes are highly sensitive to soil and plant surface temperatures, highlighting the importance of accurate estimates of these terms. The model suggests that the net flux depends not only on the foliar (stomatal) compensation point but also that of leaf litter. SURFATM-NH3 represents a comprehensive approach to studying pollutant exchanges and its link with plant and soil functioning. It also provides a simplified generalised approach (SVAT model) applicable for atmospheric transport models.
\end{abstract}

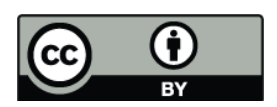

Correspondence to: E. Personne (erwan@bcgn.grignon.inra.fr)

\section{Introduction}

The exchange of trace gases and vapour pressure between terrestrial ecosystem and atmosphere is a key process of the Earth's Biosphere functioning: at the local, regional and global scales, these exchanges participate in element cycling, influencing ecosystem productivity and background pollution. With the exception of $\mathrm{CO}_{2}$, the exchange of trace gases (e.g., $\mathrm{NH}_{3}, \mathrm{O}_{3}, \mathrm{SO}_{2}, \mathrm{~N}_{2} \mathrm{O}$ ) at the surface is often included in mesoscale transport models or global scale models using a dry deposition velocity approach (Fowler et al., 1989; Wesely, 1989; Tulet et al., 2000) or emission factors (Li et al., 2001; Freibauer, 2003; Hyde et al., 2003), although recent studies use improved process based models (Grünhage and Haenel, 1997; Polcher et al., 1998; Ganzeveld et al., 2002; Nikolov and Zeller, 2003; Pinder et al., 2004; Theobald et al., 2004). In this context, this paper concentrates on atmospheric ammonia $\left(\mathrm{NH}_{3}\right)$ as a reference pollutant for the conception of exchange schemes of soil-plant-atmosphere interface that can be integrated at the lower-boundary conditions in global scale models or in mesoscale transport models.

Atmospheric ammonia $\left(\mathrm{NH}_{3}\right)$ mainly originates from agriculture (Bouwman et al., 1997; Anderson et al., 2003; Sutton et al., 2007; Zhang et al., 2008), of which animal waste is the main source (Van der Hoek, 1998; Zhang et al., 2008). Ammonia deposition leads to acidification and eutrophication of semi-natural ecosystems (Van Breemen and Van Dijk, 1988; Fangmeier et al., 1994; Dragosits et al., 2002) and to decrease of the plant biodiversity (Bobbink, 1991; Krupa, 2003; Stevens et al., 2004, 2006). The concentrations of $\mathrm{NH}_{3}$ in the environment are generally in the range 0.1 to $5 \mu \mathrm{g} \mathrm{m}^{-3} \mathrm{NH}_{3}$ and can reach several tens of $\mu \mathrm{g} \mathrm{m}^{-3} \mathrm{NH}_{3}$ in the vicinity of strong sources (Sutton et al., 1998b; Loubet

Published by Copernicus Publications on behalf of the European Geosciences Union. 
et al., 2001). As a major constituent of the plant metabolism, $\mathrm{NH}_{3}$ can either be absorbed or emitted by the vegetation (Sutton et al., 1993; Schjoerring et al., 2000). The bi-directional nature of $\mathrm{NH}_{3}$ exchange between the atmosphere and the surface has been demonstrated in many studies (Farquhar et al., 1980; Erisman and Wyers, 1993; Sutton et al., 1995, 1998a).

However, the $\mathrm{NH}_{3}$ flux above a canopy results from the combination of sources and sinks within the canopy, as emphasised by Nemitz et al. (2000a). In a grassland canopy the litter may be a strong source of $\mathrm{NH}_{3}$ as suggested by laboratory studies (Husted and Schjoerring, 1995; Mattsson and Schjoerring, 2002, 2003), but the stomata could also release $\mathrm{NH}_{3}$ following fertilisation (Husted et al., 2000; Loubet et al., 2002). However, the contribution of each compartment to the net flux is still not clear.

Modelling $\mathrm{NH}_{3}$ exchange has proven to be a useful means to interpret measured $\mathrm{NH}_{3}$ fluxes at the canopy scale, and especially to evaluate the contribution of each canopy compartment to the net flux (e.g. Nemitz et al., 2000b). However, $\mathrm{NH}_{3}$ emissions from the ground surface or from plants is known to increase exponentially with temperature, due to thermodynamic equilibria (e.g. Schjoerring, 1997), and to be controlled by stomatal resistance like any other gases (Sutton et al., 1993). Hence the $\mathrm{NH}_{3}$ exchange model needs to correctly simulate the surface temperature of emitting or absorbing compartments (stomata and litter/soil surface) as well as the stomatal resistance.

In this paper, we present a bi-directional two-layer resistance model for heat and $\mathrm{NH}_{3}$, parameterised for a grassland canopy. The model SURFATM-NH3 combines a resistive approach for the energy balance and for the $\mathrm{NH}_{3}$ exchange. It incorporates an $\mathrm{NH}_{3}$ stomatal compensation point as well as a litter or soil $\mathrm{NH}_{3}$ compensation point, and a cuticular pathway. SURFATM- $\mathrm{NH}_{3}$ model is then evaluated against measured fluxes of energy, water and ammonia, during the GRAMINAE Integrated Experiment above managed grassland at Braunschweig, Germany (Sutton et al., 2009a).

\section{Model description}

SURFATM-NH 3 is a one-dimensional, bi-directional model, which simulates the latent $(\lambda E)$ and sensible $(H)$ heat fluxes, as well as the $\mathrm{NH}_{3}$ fluxes between the biogenic surfaces and the atmosphere. SURFATM- $\mathrm{NH}_{3}$ is a resistance analogue model treating the vegetation layer and the soil layer (Monteith and Unsworth, 1990; Nemitz et al., 2001). SURFATM$\mathrm{NH}_{3}$ couples the energy balance of Choudhury and Monteith (1988), slightly modified (Appendix A), and the two-layer bi-directional $\mathrm{NH}_{3}$ exchange model of Nemitz et al. (2000b). The model includes a stomatal compensation point for $\mathrm{NH}_{3}$ $\left(\chi_{s}\right)$, and a cuticular resistance of foliage $\left(R_{w f}^{\chi}\right)$, which are modelled following Husted et al. (2000) and Nemitz et al. (2000a). It also includes a soil/litter compensation point concentration $\left(\chi_{\text {surf }}\right)$ which allows ground based $\mathrm{NH}_{3}$ emissions to be reproduced. The SURFATM-NH3 model is based on the same resistive scheme for the energy balance and the $\mathrm{NH}_{3}$ exchange and so with the same transfer resistances (aerodynamic, boundary layer, and stomatal) modulus the scalar diffusivities. The $\mathrm{NH}_{3}$ exchange is directly coupled to the energy balance via the leaf temperature $\left(T_{z_{0}^{\prime}}\right)$ and the surface temperature $\left(T_{\text {surf }}\right)$, and the humidity in the canopy $\left(e_{z_{0}}\right)$, which determine $\chi_{s}, \chi_{\text {surf }}$, and the deposition on external plant surfaces, respectively. Figure 1 shows the resistance analogue scheme for the heat, water vapour and $\mathrm{NH}_{3}$ transfer.

\subsection{Aerodynamic, boundary layer, stomatal, soil and non-stomatal resistances}

In the following, the exponent or index $i$ refers to either water vapour or $\mathrm{NH}_{3}$. The diffusivity of $\mathrm{NH}_{3}$ in air, $D_{\mathrm{NH} 3}$, and the diffusivity for water vapour in air, $D_{w}$, are taken as $D_{\mathrm{NH} 3}=2.29 \mathrm{~m}^{2} \mathrm{~s}^{-1}$ and $D_{w}=2.49 \mathrm{~m}^{2} \mathrm{~s}^{-1}$ at $25^{\circ} \mathrm{C}$ (Massman, 1998).

Aerodynamic resistances. The usual hypothesis is made of similarity between turbulent transfers of scalars, hence the aerodynamic resistances $R_{a}$ and $R_{a c}$ are supposed identical for water vapour, heat and $\mathrm{NH}_{3}$ (details given in Appendix B).

Boundary layer resistances. Following Shuttelworth and Wallace (1985) and Choudhury and Monteith (1988), the canopy boundary layer resistances $\left(R_{b f}^{i}\right.$, where $i$ stands for scalar $i$ ), are expressed as a function of the leaf boundary layer resistance and wind speed inside the canopy:

$$
R_{b f}^{i}=\left(\frac{D_{i}}{D_{w}}\right)^{-2 / 3} \cdot \frac{\alpha_{u}}{2 \cdot a \cdot \mathrm{LAI}_{s s}} \cdot\left(\frac{L W}{u\left(h_{c}\right)}\right)^{1 / 2} \cdot\left[1-\exp \left(-\frac{\alpha_{u}}{2}\right)\right]^{-1}
$$

where $\mathrm{LAI}_{s s}$ is the leaf area index (single sided projected foliage surface), $a$ is a coefficient equal to $0.01 \mathrm{~s} \mathrm{~m}^{-1 / 2}$ (Choudhury and Montheith, 1988), $\alpha_{u}$ is defined by $u(z)=$ $u\left(h_{c}\right) \cdot \exp \left[\alpha_{u}\left(z / h_{c}-1\right)\right]$, where $u(z)$ is the wind speed at height $z$, and $h_{c}$ is the canopy height, LW is the characteristic width of a the leaves (m), and $D_{i}$ and $D_{w}$ are the diffusivities of the scalar $i$ and water vapour, respectively. The ground surface boundary layer resistance is modelled following Hicks et al. (1987):

$$
R_{b s s}^{i}=\frac{2}{\kappa \cdot u_{\text {ground }}^{*}} \cdot\left(\frac{S c_{i}}{\operatorname{Pr}}\right)^{2 / 3}
$$

where $S c_{i}$ is the Schmidt number for the scalar $i\left(S c_{i}=\right.$ $v_{a} / D_{i}, D_{i}$ being the diffusivity of the scalar $i$ and $v_{a}$ the cinematic viscosity of air), Pr is the Prandtl number (0.72), and $u_{\text {ground }}^{*}$ is the friction velocity near the soil surface, which is calculated following Loubet et al. (2006):

$u_{\text {ground }}^{*}=\left(\left(u^{*}\right)^{2} \cdot \exp \left(1.2 \times \mathrm{LAI}_{s s} \times\left(\frac{z_{0 s}}{h_{c}}-1\right)\right)\right)^{1 / 2}$ 


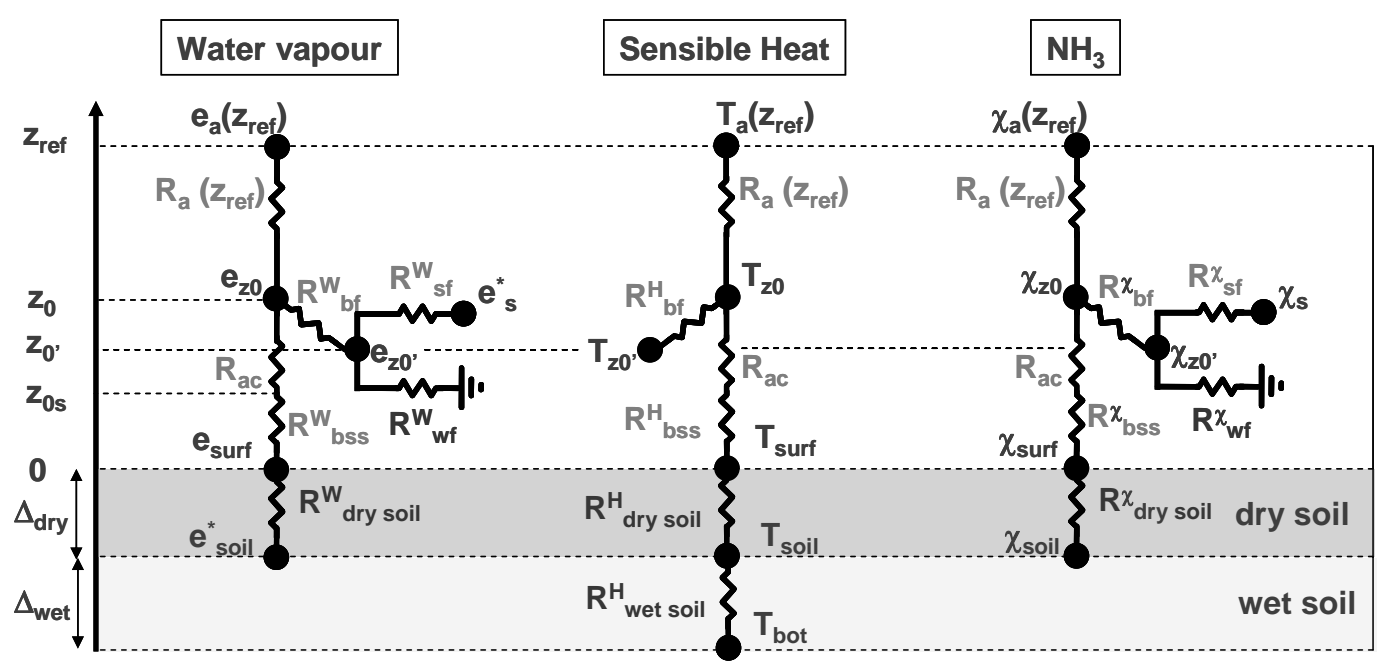

Fig. 1. Resistance scheme for water vapour, heat, and $\mathrm{NH}_{3}$ exchange models. Where $z$ is the height above ground; $e, T$ and $\chi$ refer to the water vapour partial pressure, the temperature and the $\mathrm{NH}_{3}$ concentration respectively; $R_{a}, R_{a c}, R_{b f}, R_{b s}, R_{\text {drysoil }}, R_{\text {wetsoil }}, R_{s f}$ and $R_{w f}$ are the aerodynamic resistance, the canopy aerodynamic resistance, the leaf boundary layer resistance, the soil boundary layer resistance, the soil dry resistance, the soil wet resistance, the stomatal resistance and the cuticular resistance, respectively; indexes ref, $a, z 0, z 0^{\prime}, z 0 s, s$, "surf", "soil", and "bot", refers to reference, atmospheric, canopy roughness height for momentum, canopy roughness height for scalars, soil roughness height, soil boundary, soil surface, dry/wet boundary in the soil, and bottom of the wet boundary in the soil, respectively, $\Delta_{\text {dry }}$ and $\Delta_{\text {wet }}$ are the heights of the dry and wet soil compartments respectively.

where $z_{0 s}$ is the ground surface roughness length.

Stomatal resistance. The stomatal resistance for a gas compound $i\left(R_{s}^{i}\right)$ is calculated following Jarvis (1976), as a function of the photosynthetically active radiation (PAR), and stress functions, with the parameterisation of Emberson et al. (2000) (Appendix C).

Soil resistances. Following Choudhury and Monteith (1988), the dry and wet soil layer resistances for heat conduction are calculated as:

$R_{\text {dry_soil }}^{H}=\rho_{a} \cdot c_{p} \cdot \frac{\Delta_{\text {dry }}}{\kappa_{\text {dry }}}$

$R_{\text {wet_soil }}^{H}=\rho_{a} \cdot c_{p} \cdot \frac{\Delta_{\text {wet }}}{\kappa_{\text {wet }}}$

where $\kappa$ is the thermal conductivity, $c_{p}$ specific heat capacity of air, $\rho_{a}$ the air density and the thickness $\Delta$ of each layer. The subscripts "wet" and "dry" stands for the wet and the dry layer, respectively.

For the gas transfer in the soil, the soil resistance is evaluated according to the dry soil thickness $\Delta_{\text {dry }}$ with the following resistance:

$R_{\text {dry_soil }}^{i}=\frac{\tau_{\text {soil }} \cdot \Delta_{\text {dry }}}{p \cdot D_{i}}$

where $p$ is the porosity of the soil, $\tau_{\text {soil }}$ is a tortuosity factor.

Litter resistance. Just over the soil surface and for the $\mathrm{NH}_{3}$ exchange, the model takes into account an additional diffusional resistance for transfer due to the litter laying the soil surface. Two solutions are examined in this paper. The first solution is to add the transfer resistance in series due to the transfer through the litter (from soil surface to the top of the litter). For simplicity and consistency with the soil resistance, following Schaap and Bouten (1998), the litter transfer resistance can be interpreted as in a porous medium:

$R_{\text {litt_transf }}=\frac{\tau_{\text {litt }} \cdot \Delta_{\text {litt }}}{p_{\text {litt }} \cdot D_{\mathrm{NH} 3}}$

where $\Delta_{\text {litt }}$ is the thickness of the litter, $\tau_{\text {litt }}$ the litter tortuosity and $p_{\text {litt }}$ the litter porosity.

The second solution is to consider the exchange coming from the tissues of the litter instead of the soil, and so to take into account a resistance ( $\left.R_{\text {litt_int }}\right)$ for the closed stomata of the dead leaves over the soil (Jones, 1992).

Cuticular resistance. For a simplified approach, cuticular exchanges for water vapour are supposed to be negligible compared with stomatal exchange. In contrast, for $\mathrm{NH}_{3}$ the cuticular uptake is significant. The simplest approach is to parameterise only the effect of moisture availability, without taking into account the chemical reactions with the surface or cuticular penetration (Sutton et al., 1998a; Flechard et al., 1999). Hence in SURFATM-NH 3 , the leaf surface $\mathrm{NH}_{3}$ concentration $\chi_{w f}$ is assumed to be zero with the resistance depending on microclimate. Following Sutton et al. (1993) and Sutton et al. (1995), the deposition cuticular resistance is set to $R_{w f}^{\mathrm{NH} 3}$ vary according to air relative humidity (RH in \%). The parameterisation of Milford et al. (2001a) is used here 
because the agronomic conditions of their studies are similar to that at the Braunschweig grassland (Milford et al., 2001a):

$R_{w f}^{\mathrm{NH} 3}=R_{w f_{-} \text {min }}^{\mathrm{NH} 3} \cdot \exp \left(\frac{100-\mathrm{RH}}{7}\right)$

where RH is the air relative humidity at the reference level, and $R_{w f_{-} \text {min }}^{\mathrm{NH}}=30 \mathrm{~s} \mathrm{~m}^{-1}$.

\subsection{Sub-stomatal cavity and soil surface/litter $\mathrm{NH}_{3}$ concentration}

Following Schjoerring et al. (1998), the compensation point is modelled as resulting from the thermodynamic equilibrium between $\mathrm{NH}_{3}$ in the liquid and in the gas phase as well as the acid-base equilibrium between $\mathrm{NH}_{4}^{+}$and $\mathrm{NH}_{3}$ in the liquid phase:

$\chi_{i}=K_{H A} \cdot K_{A C} \cdot \exp \left(\frac{\Delta H_{H A}^{0}+\Delta H_{A C}^{0}}{R} \cdot\left(\frac{1}{298.15}-\frac{1}{T_{i}^{K}}\right)\right) \cdot \Gamma_{i}$

where $K_{H A}$ and $K_{A C}$ are equilibrium constants at $25^{\circ} \mathrm{C}$, and $\Delta H^{0}$ are free enthalpies, $R$ is the perfect gas constant, $T^{K}$ is the temperature in Kelvin, and $\Gamma$ is the non-dimensional ammonia emission potential. Subscripts HA and AC stand for "Henry" and "dissociation", respectively; while subscript $i$ designs the compartment considered: the sub-stomatal cavity $(s)$, the interface between wet and dry soil ("soil"), or the ground surface/litter ("surf"). The temperatures have the corresponding subscript, except for the sub-stomatal cavity where the temperature $T_{s}=T_{z 0^{\prime}}$. The compensation point $\left(\chi_{i}\right)$ varies according to the temperature $T_{i}$ and $\Gamma_{i}$, where $\Gamma_{i}$ is the ratio $\left[\mathrm{NH}_{4}^{+}\right] /\left[\mathrm{H}^{+}\right]$of a canopy/soil compartment, where brackets denote concentrations in mol mol${ }^{-1}$ of available compound (i.e., not bound to soil colloids or leaf cells). Concerning the emission potential for the stomatal pathway, $\Gamma_{s}$ can in some instances be estimated from measurements of $\left[\mathrm{NH}_{4}^{+}\right]$and the $\mathrm{pH}$ of the plant apoplast, or it can represent an adjustment parameter in fitting the model to measured fluxes. In the literature, estimates of $\Gamma_{s}$ are typically in the range 60-5800 (e.g., Loubet et al., 2002; Mattson et al., 2009a, b), with the value of $\Gamma_{s}$ being governed by $\mathrm{N}$-cycling and plant metabolism (Riedo et al., 2002). In the model scheme used here (Fig. 1), concerning the soil pathway, $\Gamma_{\text {surf }}$ can either be the emission potential of the soil surface or that of the litter or dead leaves lying on the ground $\Gamma_{\text {litter }}$, while $\Gamma_{\text {soil }}$ is the emission potential at the dry-wet interface in the soil. Various models have examined the contributions of fertilisation, the soil water status, the microbiological activity and this "soil compensation point" (Genermont et al., 1998; Pinder et al., 2004). In the following, $\Gamma_{i}$ will be computed from measured $\left[\mathrm{NH}_{4}^{+}\right]$and $\left[\mathrm{H}^{+}\right]$.

\subsection{Soil water balance}

The evolution of the soil water balance is based on a twolayer approach where the soil evaporation leads to a drying of the upper dry layer, and to an increase of the thickness of this dry layer $\left(\Delta_{\text {dry }}\right)$ according to Choudhury and Montheith (1988). The plants are supposed to take up the water in the wet soil only. Hence the transpiration decreases the soil water content of the wet soil and hence the water availability for plants.

\subsection{Operation of the model}

SURFATM-NH $\mathrm{NH}_{3}$ requires input data of concentration at the reference height, meteorology, soil and vegetation stand structure. Meteorological forcing includes values of air temperature $\left(T_{a}\right)$, relative humidity $(\mathrm{RH})$, net radiation $(R n)$ and, wind speed $(u)$ at a reference height $z_{\text {ref }}$ and precipitation (Rain). Soil water content is described by the field capacity $\left(\theta_{c c}\right)$, wilting point $\left(\theta_{w p}\right)$ and dry soil humidity $\left(\theta_{H A}\right)$ in order to define the soil water availability for plants. The single sided leaf area index $\left(\mathrm{LAI}_{s s}\right)$ and the height of the canopy $\left(h_{c}\right)$ define the vegetation stand structure. The model is performed with quarter-hourly time-step.

\section{Material and methods}

\subsection{Experimental data}

The energy balance model was validated against measurements performed over a grassland field. The modelled $\mathrm{NH}_{3}$ exchange is compared to $\mathrm{NH}_{3}$ flux and concentration measurement performed at the same time. The dataset used is briefly described in this section.

The European project GRAMINAE (Grassland Ammonia Interactions Across Europe - Sutton et al., 2001, 2009a), was instigated to quantify exchange of $\mathrm{NH}_{3}$ with grasslands along an East-West transect across Europe. As part of this effort, an integrated experimental campaign took place 18 May15 June 2000 at a 6.4 ha experimental agricultural grassland of the German Federal Agricultural Research Centre Braunschweig, Völkenrode (52 $18^{\prime} \mathrm{N}, 10^{\circ} 26^{\prime} \mathrm{E} ; 79 \mathrm{~m}$ a.s.l.).

Agronomic conditions in the experiment are described by Sutton et al. (2009a, b) and show a large range of situations to evaluate the model: a) the vegetation was at first tall and dense; b) it was cut on 29 May 2000, and then left for 3 days; and c) the field was fertilized on 6 June with $108 \mathrm{~kg} \mathrm{~N}$ $\mathrm{ha}^{-1}$ as calcium ammonium nitrate. The calendar events are summarized in Fig. 2. During the measurement period before the cut, the canopy height $h_{c}$ increased from 0.65 to $0.75 \mathrm{~m}$ with a single sided leaf area index $\left(\mathrm{LAI}_{s s}\right)$ of $3.1 \mathrm{~m}^{2} \mathrm{~m}^{-2}$. After the cut, $h_{c}$ and $\mathrm{LAI}_{s s}$ were $0.07 \mathrm{~m}$ and $0.3 \mathrm{~m}^{2} \mathrm{~m}^{-2}$ and developed up to $0.32 \mathrm{~m}$ and $1.4 \mathrm{~m}^{2} \mathrm{~m}^{-2}$ by 15 June.

The model is performed with quarter-hourly time-step in order to take into account the fast changes of surface temperature and energy fluxes and the hypothesis of the stationarity of the meteorological data on this time-step (Lumley and Panofsky, 1964). Meteorological data of the experimental site (Nemitz et al., 2009), provided inputs for $T_{a}$, RH, Rn, $u$ 


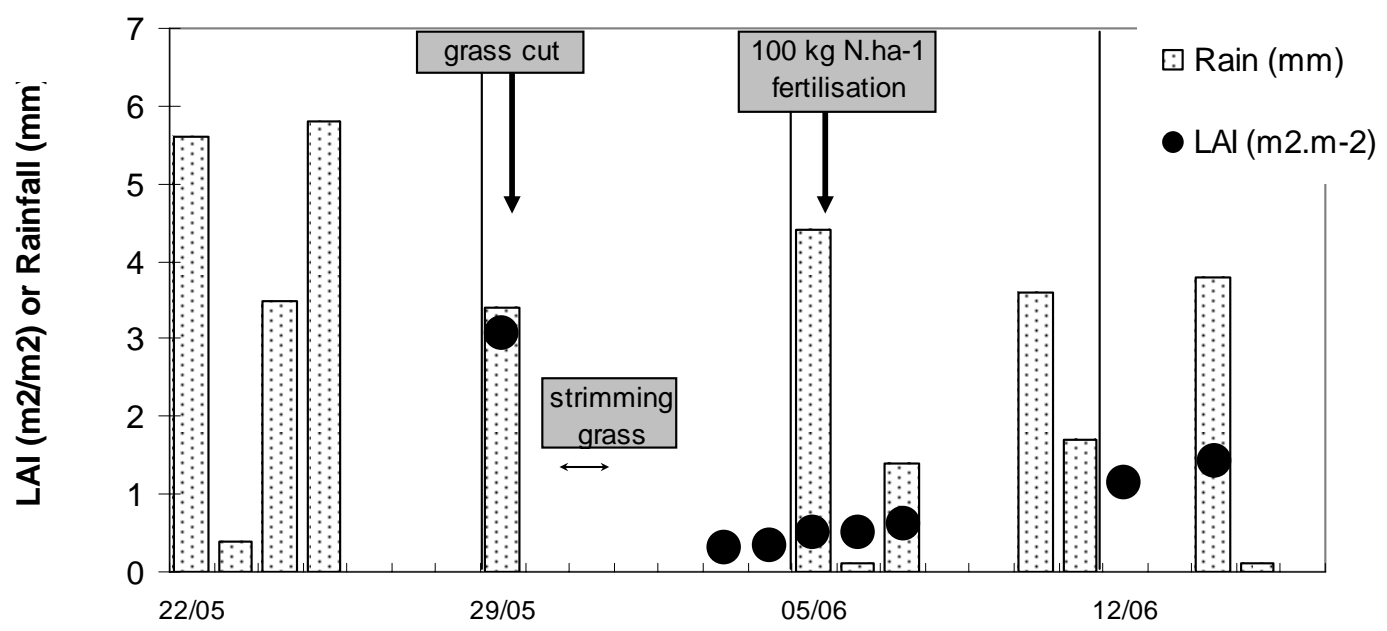

Fig. 2. Management, growth and rainfall during the GRAMINAE experiment. Rainfall is indicated by bars (in mm); LAI $\mathrm{I}_{S S}$ measurements are reported in the figure by black points (in $\mathrm{m}^{2} \mathrm{~m}^{-2}$ ); management events (cut, strimming and collecting, and fertilisation) are indicated by arrows.

and Rain, with the other input parameters used for the simulations summarized in Table 1. Model input included the atmospheric mean ammonia concentrations, $\chi_{a}$, as estimated by Milford et al. (2009). Moreover, leaf $\left(T_{z 0}^{\prime}\right)$, ground/litter ( $\left.T_{\text {surf }}\right)$ and soil $\left(T_{\text {soil }}\right)$ temperatures were estimated from measured temperature in the canopy litter and soil with fine thermocouples.

\subsection{Evaluation of heat balance model}

As discussed by Nemitz et al. (2009), the measured heat fluxes lead to a lack of closure of the energy balance $\left(R_{n}=H+\lambda E+G+\right.$ lack $)$, by about $30 \%$. However, since the model is based on the energy closure, the heat fluxes $H$ and $\lambda E$ were adjusted so that $H+\lambda E=R_{n}-G$. Based on the arguments of Twine et al. (2000), the Bowen ratio was maintained and both $H$ and $\lambda E$ were increased by $29 \%$ (Nemitz et al., 2009). The canopy height $h_{c}$, and the leaf area index were prescribed from measurements. The measured and modelled $H, \lambda E, G, T_{z 0^{\prime}}$ and $T_{\text {surf }}$ are compared against each other for estimating the validity of the heat model.

\subsection{Parameterisation of the $\mathrm{NH}_{3}$ emission potentials $\Gamma_{s}$, $\Gamma_{\text {soil }}$ and $\Gamma_{\text {litter }}$}

The model inputs for $\Gamma_{s}$ and $\Gamma_{\text {soil }}$ were derived from plant and soil measurements made during the experiment, which also provided estimates for plant litter $\left(\Gamma_{\text {litter }}\right)$. The measurements of apoplastic, litter and soil $\left[\mathrm{NH}_{4}^{+}\right]$and $\mathrm{pH}$ are described by Mattsson et al. (2009a), Herrmann et al. (2009), with the synthesis of the different values reported by Sutton et al. (2009b). Based on this synthesis, we interpolated the measured values to provide simplified profiles of $\Gamma_{s}, \Gamma_{\text {soil }}$ and $\Gamma_{\text {litter }}$ through the experiment (Fig. 3). The huge range of measured values between $\Gamma_{s}, \Gamma_{\text {soil }}$ and $\Gamma_{\text {litter }}$ is apparent

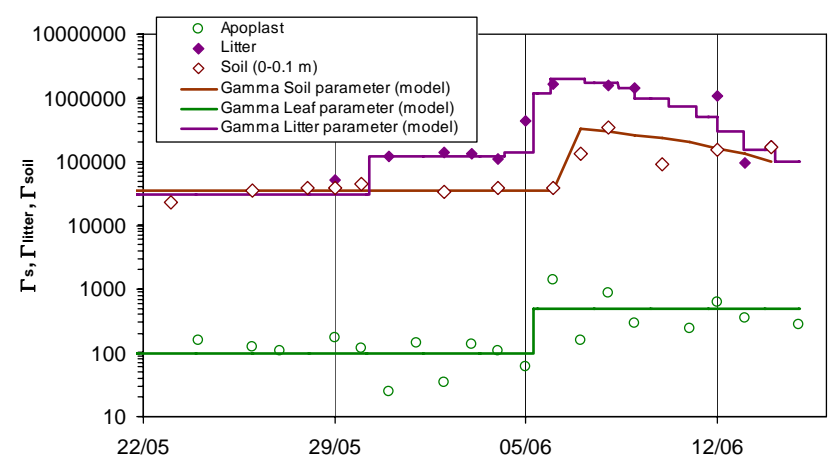

Fig. 3. Evolution of the emission potential for the soil $\left(\Gamma_{\text {soil }}\right)$, the plant $\left(\Gamma_{S}\right)$ and the litter $\left(\Gamma_{\text {litter }}\right)$. Points results from measurements of Mattsson et al. (2009a, b) and Herrmann et al. (2009) as synthesized by Sutton et al. (2009b). The solid lines represent the continuous time series of values applied here in the model simulations.

in Fig. 3. $\Gamma_{s}$ values were rather modest, between 100-600, with an increase occurring after fertilization. Values of $\Gamma_{\text {soil }}$ were much larger, especially after fertilization, indicating the ground surface as the dominant emission pathway for this period. It is notable, however, that $\Gamma_{\text {litter }}$ values were very high in comparison with the values of $\Gamma_{s}$ and $\Gamma_{\text {soil }}$, both before and after the cut, while after fertilization $\Gamma_{\text {litter }}$ increased further, possibly due to the presence of fertilizer ammonium adsorbing to the litter.

The interpolated lines in Fig. 3 provided the input $\Gamma$ values for the model simulations, using two different approaches, named scenario S1 and scenario S2. In the first approach (S1), the ground surface emission was parameterised using the measured values of $\Gamma_{\text {soil }}$, with hypothesis that the $\mathrm{NH}_{3}$ comes from the boundary between wet and dry soil 
Table 1. List of the input parameters used in the SURFATM-NH3 model. The origin of the used values is indicated in the last column.

\begin{tabular}{|c|c|c|c|c|}
\hline & Physical constants & Values (at $20^{\circ} \mathrm{C}$ ) & & Reference \\
\hline$\rho_{a}$ & density of air $\left(20^{\circ} \mathrm{C}\right)$ & $1.19\left(\mathrm{~kg} \mathrm{~m}^{-3}\right)$ & & $\begin{array}{l}\text { Monteith and Unsworth } \\
\text { (1990) }\end{array}$ \\
\hline$c_{p}$ & Specific heat capacity of air & $1010\left(\mathrm{~J} \mathrm{~kg}^{-1} \mathrm{~K}^{-1}\right)$ & & $\begin{array}{l}\text { Monteith and Unsworth } \\
\text { (1990) }\end{array}$ \\
\hline$D_{\mathrm{NH} 3}$ & Molecular diffusion for $\mathrm{NH}_{3}$ & $2.29 \times 10^{-5}\left(\mathrm{~m}^{2} \mathrm{~s}^{-1}\right)$ & & Massman (1998) \\
\hline$D_{W}$ & Molecular diffusion for vapour & $2.49 \times 10^{-5}\left(\mathrm{~m}^{2} \mathrm{~s}^{-1}\right)$ & & Massman (1998) \\
\hline$v_{a}$ & Air cinematic viscosity $\left(20^{\circ} \mathrm{C}\right)$ & $1.55 \times 10^{-5}\left(\mathrm{~m}^{2} \mathrm{~s}^{-1}\right)$ & & $\begin{array}{l}\text { Monteith and Unsworth } \\
\text { (1990) }\end{array}$ \\
\hline $\operatorname{Pr}$ & Prandt number & $0.71(-)$ & & $\begin{array}{l}\text { Grünhage and Haenel } \\
\text { (1997) }\end{array}$ \\
\hline \multirow[t]{2}{*}{$\mathrm{Sc}^{\mathrm{NH} 3}$} & Schmidt number for $\mathrm{NH}_{3}$ & $0.92(-)$ & & $\begin{array}{l}\text { Grünhage and Haenel } \\
\text { (1997) }\end{array}$ \\
\hline & Chimical constants & & & \\
\hline$K_{H A}$ & Henry Constant & $10^{-3.14}(-)$ & & Loubet (2000) \\
\hline$K_{A C}$ & $\begin{array}{l}\text { Dissociation constant for acid-base disso- } \\
\text { ciation } \mathrm{NH}_{4}^{+} / \mathrm{NH}_{3}\end{array}$ & $10^{-9.25}\left(\mathrm{moll}^{-1}\right)$ & & Bates and Pinching (1950) \\
\hline$\Delta H_{A C}^{0}$ & $\begin{array}{l}\text { Free Enthalpy for acid-base dissociation } \\
\mathrm{NH}_{4}^{+} / \mathrm{NH}_{3}\end{array}$ & $52.21\left(\mathrm{~kJ} \mathrm{~mol}^{-1}\right)$ & & Flechard et al. (1999) \\
\hline \multirow[t]{2}{*}{$\Delta H_{H A}^{0}$} & Free Enthalpy for $\mathrm{NH}_{3}$ volatilisation & $34.18\left(\mathrm{~kJ} \mathrm{~mol}^{-1}\right)$ & & Flechard et al. (1999) \\
\hline & Physical surface parameters & & & \\
\hline$\kappa_{\text {wet }}$ & Thermal conductivity for wet soil & $1.8\left(\mathrm{~W} \mathrm{~m}^{-1} \mathrm{~K}^{-1}\right)$ & Range $[1.6 ; 2.2]$ & $\begin{array}{l}\text { Monteith and Unsworth } \\
\text { (1990) }\end{array}$ \\
\hline$\kappa_{\text {dry }}$ & Thermal conductivity for dry soil & $0.28\left(\mathrm{~W} \mathrm{~m}^{-1} \mathrm{~K}^{-1}\right)$ & Range $[0.2 ; 0.3]$ & $\begin{array}{l}\text { Monteith and Unsworth } \\
\text { (1990) }\end{array}$ \\
\hline$\tau_{\text {soil }}$ & Soil tortuosity & $2.5(-)$ & & $\begin{array}{l}\text { Choudhury and Monteith } \\
\text { (1988) }\end{array}$ \\
\hline$\tau_{\text {litt }}$ & litter tortuosity & $1.5(-)$ & & Estimated \\
\hline$p$ & Soil porosity & $0.36(-)$ & & $\begin{array}{l}\text { Estimated from measured } \\
\text { soil saturation }\end{array}$ \\
\hline$p_{\text {litt }}$ & Litter porosity & $0.9(-)$ & & $\begin{array}{l}\text { Estimated from bibliogra- } \\
\text { phy (Schaap and Bouten } \\
\text { 1998; Tuzet et al., 1993) }\end{array}$ \\
\hline$\Delta_{\text {litt }}$ & Litter thickness & $0.005(\mathrm{~m})$ & & $\begin{array}{l}\text { Estimated from litter sam- } \\
\text { ple measured (David et al., } \\
\text { 2009a) }\end{array}$ \\
\hline$\alpha_{u}$ & Attenuation coefficient for wind speed & $4.2(-)$ & & $\begin{array}{l}\text { Choudhury and Montheith } \\
\text { (1988) }\end{array}$ \\
\hline$k_{R n}$ & Radiation attenuation coefficient & $0.65(-)$ & & Guyot (1998) \\
\hline$z_{0 \text { soil }}$ & Soil roughness & $0.02(\mathrm{~m})$ & & \\
\hline$z_{0}$ & Vegetation roughness & Calculated (m) & & Tuzet et al. (1992) \\
\hline$d$ & Vegetation displacement displacement & Calculated (m) & & Tuzet et al. (1992) \\
\hline$L W$ & Characteristic width of the leaves & $0.05(\mathrm{~m})$ & & \\
\hline$h_{c}$ & Vegetation height & Measured (m) & $0.07 \mathrm{~m}-0.76 \mathrm{~m}$ & Sutton et al. $(2002,2008)$ \\
\hline $\mathrm{LAI}_{s s}$ & Leaf Area Index single side & Measured & $0.14-3.1$ & Sutton et al. $(2002,2008)$ \\
\hline
\end{tabular}

(level "soil" in Fig. 1). Therefore, the value of $\Gamma_{\text {soil }}$ was associated with the temperature at this level $\left(T_{\text {soil }}\right)$ and the soil resistance $\left(R_{\text {dry_soil }}^{\mathrm{NH}}\right)$ integrating an additional transfer resistance through the litter ( $R_{\text {litt_transf }}$, Eq. 7$)$. In the sec- ond approach (S2), the ground surface emission was parameterised using the measured values of $\Gamma_{\text {litter, with the }}$ hypothesis that the associated temperature is that of the soil surface ( $T_{\text {surf }}$ in Fig. 1), with the stomata of the litter 

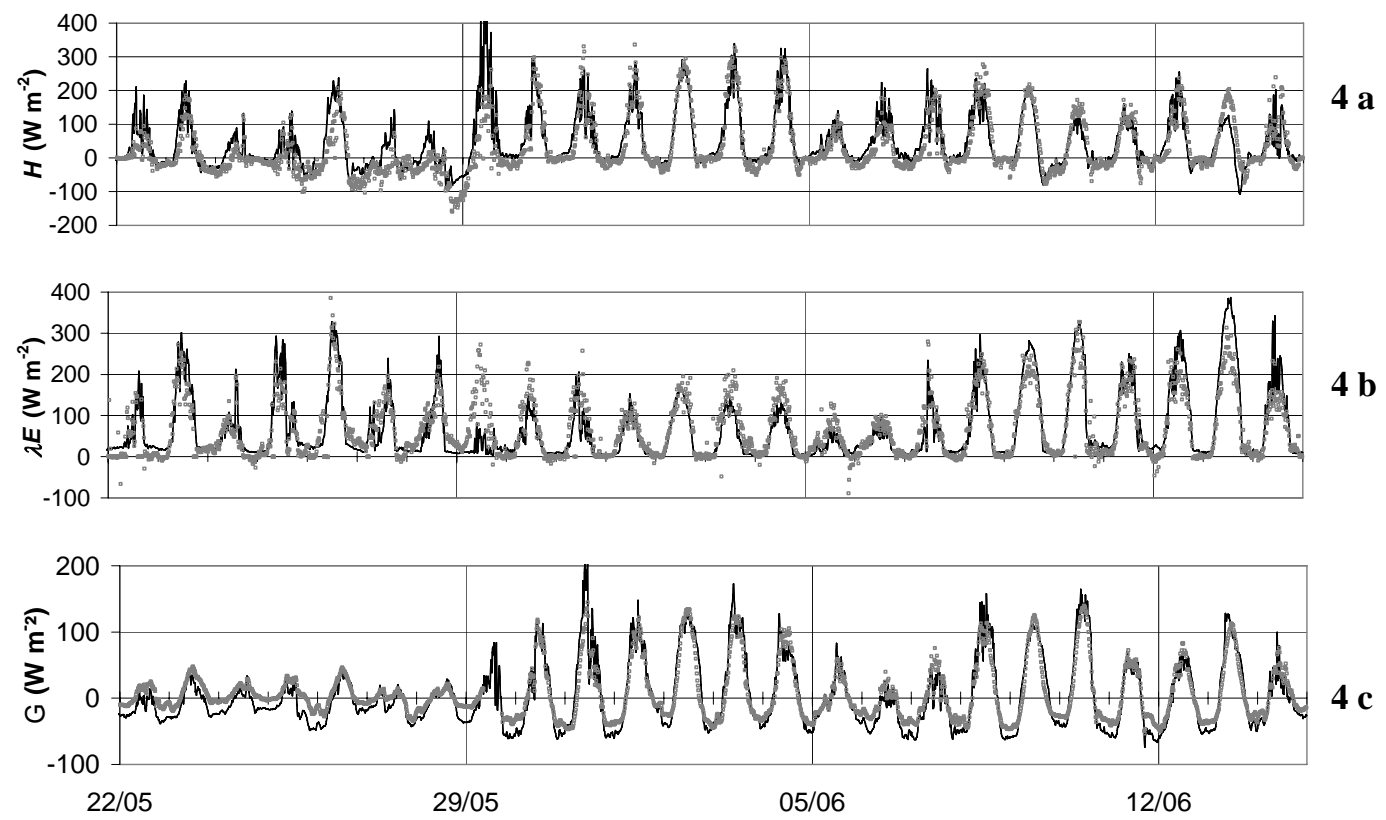

Fig. 4. Comparison of modelled (lines) and measured (dots) components of the energy balance through the experiment: (a) sensible heat flux $H$, (b) latent heat flux $\lambda E$, and (c) soil heat flux $G$.

assumed to be inactive providing an additional resistance $R_{\text {litt_int }}=5000 \mathrm{~s} \mathrm{~m}^{-1}$ (Jones, 1992) in the simulation.

In both approaches, the modelled $\Gamma_{s}$ is used to estimate the sub-stomatal cavity $\mathrm{NH}_{3}$ concentration $\chi_{s}$ using based on Eq. (9).

\section{Results}

The simulations of SURFATM- $\mathrm{NH}_{3}$ were compared with the detailed energy balance measurements reported by Nemitz et al. (2009) and with the measured mean $\mathrm{NH}_{3}$ fluxes determined by aerodynamic gradient method, as reported by Milford et al. (2009), including appropriate corrections for advection where necessary (Loubet et al., 2009). For certain days there was significant uncertainty in the mean fluxes, so that Milford et al. (2009) also reported an "alternative estimate" of the flux. Further comparison with flux measurements using a surface dispersion model (Loubet et al., 2006) and relaxed eddy accumulation (Hensen et al., 2008), provided independent data to distinguish the most robust flux estimates for these uncertain days (Sutton et al., 2009b). The synthesized flux dataset was thus used for comparison with the model flux estimates of SURFATM- $\mathrm{NH}_{3}$.

\subsection{Energy budget}

No calibrations were used for the part of the model which treats the energy budget. Figure 4 represents the various fluxes of the energy budget. The corrections of Twine et al. (2000), accounting for eddy covariance methods and di- rect measurements of $R n$, were applied and allow a coherent energy budget to be estimated with independent measurements of $H$ and $\lambda E$ : the model shows a close agreement to the measured fluxes throughout the comparison (Table 2). A major change in fluxes magnitude occurs from 29 May. The grassland cut led to increase the total heat flux $(H)$ and the soil heat conduction $(G)$. This clear change is not observed for the modelled latent heat flux $(\lambda E)$ on 29 May, and may result from a transient increase in evaporation and drying of the grass cuttings prior to their removal.

\subsection{Temperature}

The modelled surface temperature of the soil and the foliage are the equilibrium variables of the energy budget. These variables are the key-connections between the energy budget and the ammonia exchange. Figure 5 shows the results of measured and modelled temperatures before and after the cut. The modelled soil surface and leaf temperature ( $T_{\text {surf }}$ and $\left.T_{z 0^{\prime}}\right)$ are higher than the air temperature $\left(T_{a}\right)$ during the day, and vice versa during the night (Fig. 5c). During the day, the vegetation temperature is ranged between the measurements of the top and the bottom of the canopy. The agreement between the model and the measurements is within $2.5^{\circ} \mathrm{C}$ for $T_{z 0^{\prime}}$ ("foliage temperature"), except for the days 29 to 31 May during which the model overestimates the measurements (Fig. 5b). For the litter temperature, the agreement is within $2^{\circ} \mathrm{C}$ for $T_{\text {surf }}$ ("ground surface temperature") before the cut but it can be seen an overestimation of the model three days after the cut and an underestimation from the 8 June (Fig. 5a). The worst agreements are just following the cut 

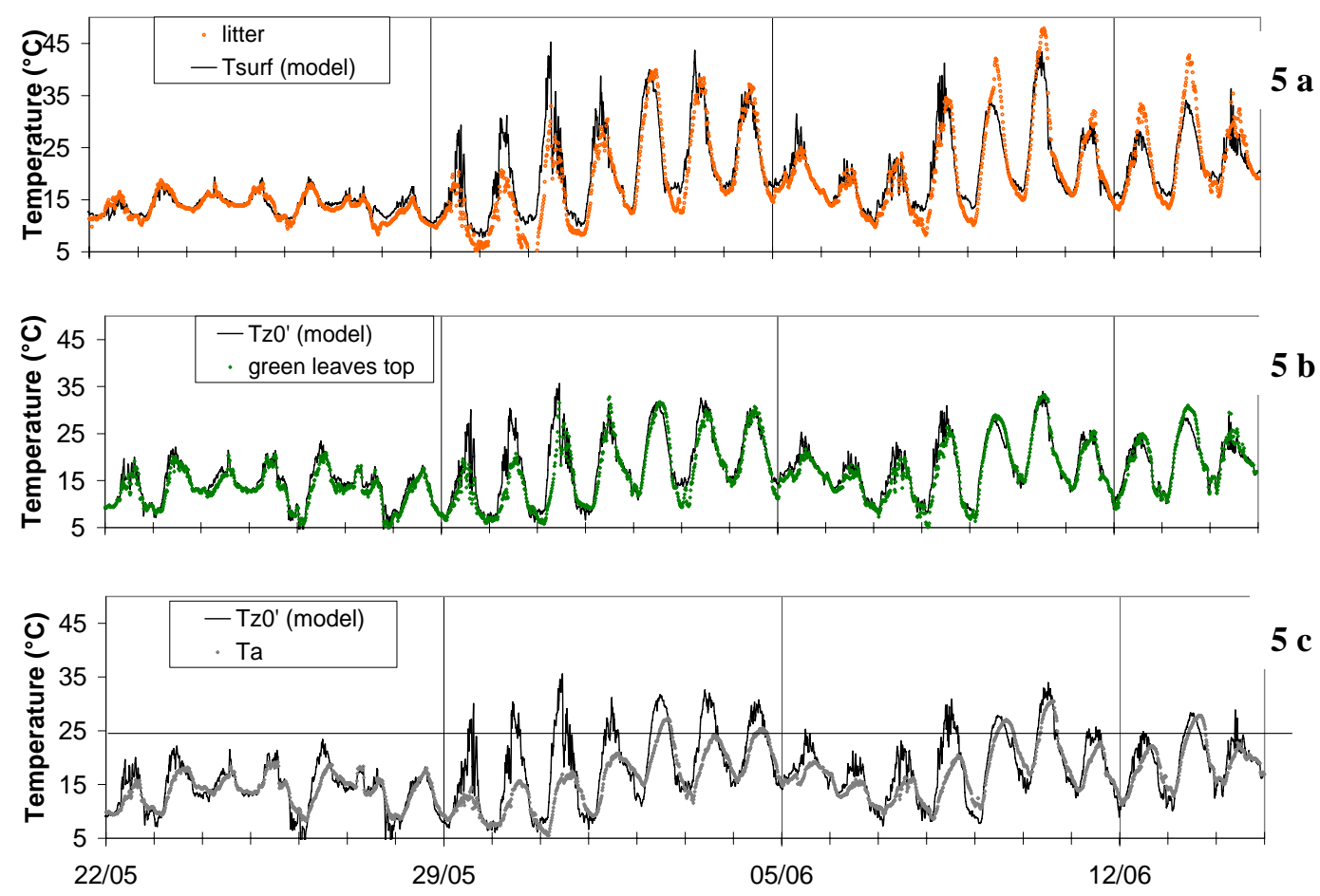

Fig. 5. Comparison of modelled (lines) and measured (dots) temperatures through the experiment: (a) ground surface temperature, and (b) canopy temperature. The measured air and canopy temperature are also shown in (c) for comparison.

where the difference between measured and modelled temperatures reaches $5^{\circ} \mathrm{C}$ for $T_{z 0^{\prime}}$ and $12^{\circ} \mathrm{C}$ for $T_{\text {surf. However }}$ before the cut, the agreement is much better $1^{\circ} \mathrm{C}$ for $T_{z 0^{\prime}}$ and $2^{\circ} \mathrm{C}$ for $T_{\text {surf }}$. It can be underlined that these differences are lower than the difference between the measured air and surface temperature of 5 to $7^{\circ} \mathrm{C}$ for the difference $\left(T_{a}-T_{z 0^{\prime}}\right)$ and 10 to $15^{\circ} \mathrm{C}$ for the difference $\left(T_{a}-T_{\text {litter }}\right)$

\subsection{Ammonia fluxes and dynamics of the emission potential}

Figure 6 presents the comparison with the modelled total $\mathrm{NH}_{3}$ fluxes and the measured $\mathrm{NH}_{3}$ fluxes above the field. From 21 to 29 May (before the cut), the $\mathrm{NH}_{3}$ fluxes ranged between a deposition of $-50 \mathrm{ng} \mathrm{NH}_{3} \mathrm{~m}^{-2} \mathrm{~s}^{-1}$ to an emission of $+40 \mathrm{ng} \mathrm{NH}_{3} \mathrm{~m}^{-2} \mathrm{~s}^{-1}$. Following cutting, $\mathrm{NH}_{3}$ emissions increased up to up $500 \mathrm{ng} \mathrm{NH}_{3} \mathrm{~m}^{-2} \mathrm{~s}^{-1}$ (Fig. 6). These emissions are an order of magnitude greater than the typical emission observed over the grassland previous to cutting. Following fertilization on 6 June, the fluxes immediately increased up to $2000 \mathrm{ng} \mathrm{NH}_{3} \mathrm{~m}^{-2} \mathrm{~s}^{-1}$. These high emission values continued for a few days before progressively decreasing to similar emission fluxes prior to fertilization at daytime maxima near $500 \mathrm{ng} \mathrm{NH}_{3} \mathrm{~m}^{-2} \mathrm{~s}^{-1}$. The typical diurnal pattern of emission fluxes after the cut and the fertilisation typically exhibited a clear increase in emission starting at 06:00 and reverting to near zero at 20:00 (Fig. 6).
The simulations are based on two scenarios: the soil emission scenario (S1) and the litter emission scenario (S2). Both the simulations using litter and soil emissions reproduce the diurnal dynamics of emissions.

Concerning the scenario $\mathrm{S} 1$ with the soil emission, it overestimates the emission of the ground surface before the cut and underestimates by a factor of 2 the emission after the cut. After fertilization, it is notable that the simulation using the soil source parameterisation does not reproduce the emission just after fertilization on 5 June. By contrast, while the simulation for the 7 and 9 June presents close agreements with the measurements, the simulation deviates from the total $\mathrm{NH}_{3}$ flux the subsequent days.

Concerning the scenario $\mathrm{S} 2$, the simulation reproduces satisfactorily the fluxes before and after the cut, with a tendency for the model to reproduce emission peaks too high by a factor of 1.2 after the cut and by a factor of 2.2 on the 2 June, one of the hottest days of the experiment. This scenario S2 also underestimates the measured emission flux on the day of the cut. Just after the fertilization, this scenario reproduces fairly well the magnitude and the pattern of the fluxes (especially the night time emissions during the nights 5-6 June and 6-7 June), but overestimates the emission 8, 9 and 10 June, which were three particularly hot days.

SURFATM- $\mathrm{NH}_{3}$ clearly simulates the increase in $\mathrm{NH}_{3}$ emission following cutting using both the litter and soil emission parameterisations, even though Fig. 3 indicates that 

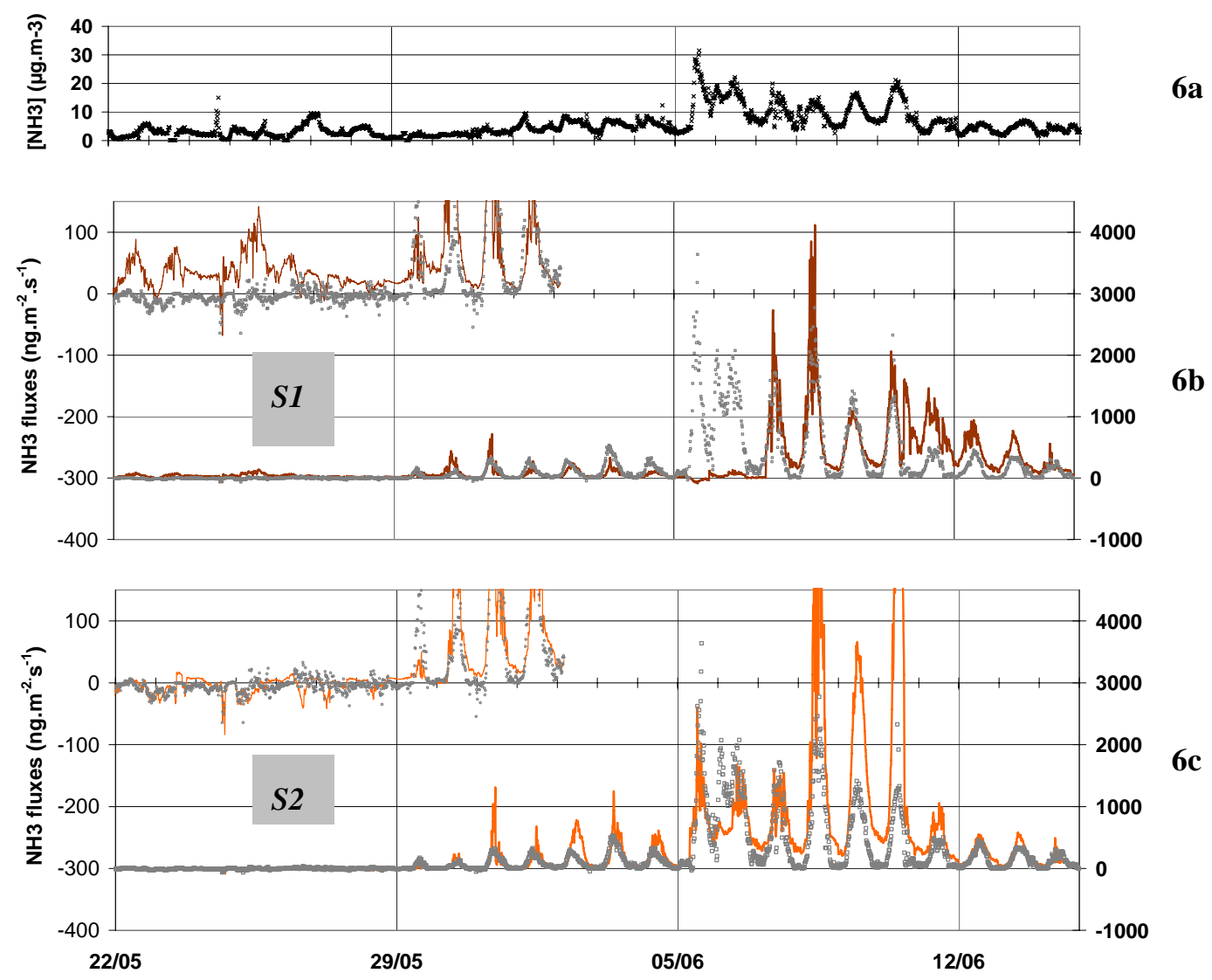

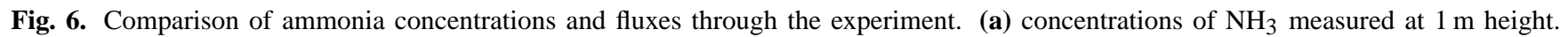
Modelled (lines) and measured (dots) $\mathrm{NH}_{3}$ fluxes are based on (b) the soil emission scenario $S 1$ and (c) and the litter emission scenario $S 2$. Note that there are two y-axis in order to magnify the period 21 May to 31 May (left y-axis), whereas the right axis applies for following period.

there was no increase in $\Gamma_{\text {soil }}$. Therefore, the increased $\mathrm{NH}_{3}$ emissions in the two simulations (S1 and S2) must be to a large extent a result of factors other than changes in $\Gamma$ values. In particular, the removal of the overlying canopy (which would recapture a fraction of the ground surface emission) and the warmer ground temperatures (Fig. 5) explain the main changes in the modelled estimates. Nevertheless, the modelled soil source scenario (S1) does not fully explain all the increase in $\mathrm{NH}_{3}$ fluxes observed during this period (apart from 30-31 May). The measured larger emissions on 1-4 June are thus more closely simulated using the litter $\mathrm{NH}_{3}$ source scenario (S2), including the larger values on 3 June.

For the post-fertilization period, both the soil and litter source parameterisations (S1 and S2) demonstrate the further increase in $\mathrm{NH}_{3}$ emission, which is closely coupled to the changing measured values of $\Gamma_{\text {soil }}$ and $\Gamma_{\text {litter }}$ over this period (Fig. 3).

\section{Discussion}

The close agreement for $H, \lambda E$ and $G$ fluxes (Fig. 4) between measurements and simulations ensures a consistent calibration for the physical and biological parameters (Table 1). It can be supposed that the values used for the stomatal resistance and soil thermal conductivities are well adapted to the experimental site. The correction of Twine et al. (2000) was used to close the measured energy budget. However, without Twine's corrections the modelled latent heat flux $(\lambda E)$ is overestimated by $26 \%$, while the modelled sensible heat flux $(H)$ is only overestimated by $13 \%$, hence suggesting that the measured $\lambda E$ was probably underestimated, which tends to support the conclusion of Nemitz et al. (2008).

The litter is taken into account in the resistance scheme of the energy balance model with an additional resistance in series $\left(R_{\text {litt_transf }}\right)$. This litter layer reduces the transfer of sensible heat between the soil and the canopy (larger $R_{\text {drysoil }}^{H}$ ) and reduces $G$, which was overestimated by the model at night by $18 \%$. The litter would also induce an additional water 
Table 2. Coefficients of the linear regressions for the comparisons model $=f$ (measure) in terms of energy fluxes.

\begin{tabular}{ll}
\hline & Whole period (22 May-15 June) \\
\hline$H$ & $y=0.90 \mathrm{x}+17\left(r^{2}=0.88\right)$ \\
$\lambda E$ & $y=1.02 \mathrm{x}+6\left(r^{2}=0.87\right)$ \\
$G$ & $y=0.72 \mathrm{x}-8\left(r^{2}=0.85\right)$ \\
\hline
\end{tabular}

"reservoir" in the canopy which would lead to evaporation during the day and condensation at night, hence modifying the energy partition at the ground (Tuzet et al., 1993).

The modelled canopy temperature $T_{z 0^{\prime}}$ is close to the measured temperature of top green leaves, differing by less than $2.5^{\circ} \mathrm{C}$, which is less than the difference between the measured $T_{a}$ and $T_{z 0^{\prime}}$ (Fig. 5c and Table 3). The soil surface temperature $T_{\text {surf }}$ is also well simulated except for three days following the cut where it reaches 3 to $10^{\circ} \mathrm{C}$ above the measured $T_{\text {surf }}$ (30 May to 1 June) and at the end of the experiment (after 8 June) where the model underestimates by $2^{\circ} \mathrm{C}$ to $8^{\circ} \mathrm{C}$ the measured $T_{\text {surf. The overestimation is certainly }}$ linked with the presence of the grass left on the field during 30 to 31 May (collecting the 1 June) inducing a radiative protection of the litter and an increase of the resistance for heat. On the other hand the underestimation at the end of the experiment is probably linked to the progressive drying of the litter tissues, which would induce a higher decrease of the litter evaporation and so an increase of the ground heat transfer. This last point is confirmed by the Fig. $4 a$ and $b$ showing a slightly overestimation of the modelled $\lambda E$ and underestimation of the modelled $H$ during this last period.

\subsection{Uncertainty in stomatal resistance and emission potential}

The pretty good agreement between the modelled and measured heat fluxes and temperatures also implies that the stomatal resistance $R_{s}^{W} R_{s}^{\mathrm{NH} 3}$ and the canopy temperatures $\left(T_{z 0^{\prime}}\right.$ and $T_{\text {surf }}$, respectively), and humidity are all correctly predicted. This is without questioning the Twine et al. (2000) correction which changes $R_{S}$ substantially. A new parameterisation would need to multiply $R_{s}^{W}$ by two in order to reproduce the range of the latent heat flux directly measured, without correction.

An increase of $100 \%$ of the stomatal resistance increases the heat exchanges and increases the gap between model and measurements by $19 \%$ for the heat fluxes $H$ and $3 \%$ for the soil heat conduction $G$ while this variation for the stomatal resistance induces a decrease of $25 \%$ for the latent heat flux $\lambda E$. Such variation of the stomatal resistance induces only a small change of the temperature smaller than $0.5^{\circ} \mathrm{C}$. The uncertainty on $R_{S}$ based on the error of $H, \lambda E$ and $G$ induces a small effect on the surface temperatures.
Table 3. Mean difference between the air temperature $(T a)$ and the ground surface temperature ( $T_{\text {surf }}$ ) or the vegetation surface temperature $\left(T_{z 0^{\prime}}\right)$ for the 3 periods of the experiment (before the cut, after the cut and after the fertilization). The mean diurnal differences are calculated from each time step on the period 05:00 to 19:00.

\begin{tabular}{lcc}
\hline & $\begin{array}{c}\left(T_{z 0^{\prime}-T a}\right) \\
\text { in }{ }^{\circ} \mathrm{C}\end{array}$ & $\begin{array}{c}\left(T_{\text {surf }}-T a\right) \\
\text { in }{ }^{\circ} \mathrm{C}\end{array}$ \\
\hline $\begin{array}{l}\text { Whole period } \\
(22 \text { May-15 June })\end{array}$ & +2.7 & +4.2 \\
$\begin{array}{l}\text { Precut diurnal period } \\
(05: 00-19: 00)\end{array}$ & +1.6 & +0.2 \\
$\begin{array}{l}\text { Post-cut diurnal period } \\
(05: 00-19: 00)\end{array}$ & +5.1 & +8.0 \\
$\begin{array}{l}\text { Fertilization diurnal period } \\
(05: 00-19: 00)\end{array}$ & +2.2 & +5.2 \\
\hline
\end{tabular}

The temperatures $T_{z 0^{\prime}}$ and $T_{\text {surf }}$ are very sensitive parameters of the $\mathrm{NH}_{3}$ exchange model since the compensation points $\chi_{s}$ and $\chi_{\text {surf }}$ are exponentially dependent on temperature (Eq. 9). The coupling between the energy balance model and the pollutant exchange model is essentially made via $T_{z 0^{\prime}}$ and $T_{\text {surf }}$. Hence the fact that these two modelled temperatures are in agreement with the measured ones within $2^{\circ} \mathrm{C}$ (in general), implies a potential error on $\chi_{s}$ and $\chi_{\text {surf }}$ of $20 \%$.

\subsection{Dynamics of the ammonia exchange}

Examining the period prior to the cut (Fig. 6a), $\mathrm{NH}_{3}$ fluxes were lower than $100 \mathrm{ng} \mathrm{m}^{-2} \mathrm{~s}^{-1}$ and deposition was predominant. This deposition would have been governed by the plant exchanges according to the covering foliage of plant $\left(\mathrm{LAI}_{s s}=3\right)$. Similar fluxes have been reported elsewhere for managed grassland (Milford et al., 2001a) where deposition fluxes were similar to our experiment at around $50 \mathrm{ng} \mathrm{\textrm {NH } _ { 3 }}$ $\mathrm{m}^{-2} \mathrm{~s}^{-1}$. In these conditions of deposition, when vegetation is dense, the total modelled $\mathrm{NH}_{3}$ flux is sensitive to the parameterisation of the cuticular deposition. For ammonia, atmospheric water content (expressed here as relative humidity) is a determinant variable, and in this simplified approach based on the parameterisation of Milford et al. (2001a, b), this variable alone is sufficient to explain much of the pattern in deposition. In fact, this approach is simple and operational with only meteorological forcing ( $\mathrm{RH}$ at the reference height $z_{\text {ref })}$ ), but does not reproduce $\mathrm{NH}_{3}$ desorption processes (Sutton et al., 1998a; Flechard et al., 1999) or specific microclimate in the vicinity of the foliage. However, it remains consistent for the model because this approach is validated for various conditions and plant surface types (van Hove et al., 1989; Sutton et al., 1995; Nemitz et al., 2001). The first improvement could be simply done by using the relative humidity of the air in the vicinity of the foliage (at the level $z_{0}^{\prime}$ ) instead of the air ambient RH on condition 
that the parameterisation of Milford et al. (2001a) remains adapted to this change of compartment level $\left(z_{0}^{\prime}\right.$ instead of $\left.z_{\text {ref }}\right)$. The cuticular exchanges could also be treated in a dynamical approach, as an electric capacitor with a surface charge $\chi_{w f}$, which may be released under certain conditions (Sutton et al. 1998a). The exchange conditions are related to the surface chemical processes, the air vapour pressure and the temperatures, and to the climatic events (rainfall and surface leaching) (Flechard et al., 1999). The potential importance of these cuticular adsorption/desorption processes for the Braunschweig dataset are investigated by Burkhardt et al. (2009).

After the vegetation is cut, the role of the ground surface exchange is enhanced as is the influence of the ground surface temperature. The role of ground temperature was particularly important during the period after cutting, where soil surface temperature increased by $15^{\circ} \mathrm{C}$ during the day in comparison with values at night. The sensitivity was tested to the choice of surface temperature estimate used in the model. Replacing the surface temperatures $\left(T_{z 0^{\prime}}\right.$ and $\left.T_{\text {surf }}\right)$ by the air temperature at the reference level $(T a)$ substantially altered simulated fluxes, which underlines the importance of the coupling between energy balance model and the pollutant exchange model. This change resulted in an underestimation of the modelled $\mathrm{NH}_{3}$ flux during the diurnal periods: before the cut, the total $\mathrm{NH}_{3}$ fluxes only increases of $8 \%$ due to this substitution, but after the cut, the modelled total $\mathrm{NH}_{3}$ flux becomes four times lower than the measurements and after fertilization, two times lower except for the 9 and 10 June during which the model agrees with the measurements. These general discrepancies are due to the lack of surface warming during the night (see Table 3). In parallel, it can be underlined that the gap between the vegetation temperature and the litter temperature reaches $3^{\circ} \mathrm{C}$. This gap would affect the modelled compensation points by a potential error of about 30 to $70 \%$ if only one bulk temperature of the cover vegetation was calculated by a big leaf approach.

The ammonia with the leaf apoplast were parameterised by values of emission potential $(\Gamma)$ ranging between 100 600 (Fig. 3), which are typical of other similar measurements (e.g., Loubet et al., 2002).

In a more detailed analysis, the decrease of this soil emission potential should be take into account the degradation of litter on the soil surface and the dilution or leaching with soil water in order to improve of the simulated results in comparison with measurements, and these aspects should be considered in future work. This result demonstrates the influence of the agronomic/soil management and the link between the microclimate and the pollutant exchange. Similarly, while overall agreement was found between the model and the measurements, as well as the results of parallel cuvette measurements (David et al., 2009a), the measured $\Gamma_{\text {soil }}$ and $\Gamma_{\text {litter }}$ values must also be considered as uncertain. For example, mineralization of $\mathrm{NH}_{4}^{+}$in litter may be considered to depend on moisture availability, so that loss of $\mathrm{NH}_{3}$ to the atmosphere will deplete $\Gamma_{\text {litter values substantially until more }}$ mineralization is able to occur. Such dynamics, not included in the present simulation can easily explain the differences between model and measurements that were observed.

\subsection{Origin of the ground emission}

The model gives contrasting results for the $\mathrm{NH}_{3}$ flux according to the choice scenario $\mathrm{S} 1$ or $\mathrm{S} 2$. The scenario $\mathrm{S} 1$ is based only soil emissions and shows much less agreement with the measurements than S2. Several explanations could explain the failure of this "soil" scenario to reproduce the $\mathrm{NH}_{3}$ emission.

Before the cut, the simulated total $\mathrm{NH}_{3}$ flux according to $\mathrm{S} 1$ is too high compared with measurements indicating a too large ground emission. If the vegetation absorption is considered to be realistic, two ways could explain the difference between the simulation and the measurements: $(i)$ uncertainty of the measured soil $\mathrm{pH}$ and/or the freely soil $\mathrm{NH}_{4}^{+}$availability for volatilization propagates to the emission potential $\left(\Gamma_{\text {soil }}\right)$, and (ii) the litter resistance $\left(R_{\text {litt_transf }}\right)$ or the specific soil resistance for $\mathrm{NH}_{3}\left(R_{\text {dry_soil }}^{\mathrm{NH}}\right)$ is too low.

After the cut, the results are reversed: the simulated emissions for $\mathrm{S} 1$ are smaller than the measurements. A modification of one of the previous ways by setting the emission potential $\left(\Gamma_{\text {soil }}\right.$ [for simulation S1] $=$ measured $\Gamma_{\text {soil }}$ divided by 4$)$ or the litter resistance $\left(R_{\text {litt_transf }}=3800 \mathrm{~s} \mathrm{~m}^{-1}\right.$, original resistance multiplied by 10) during the period before the cut would improve the agreement between the simulation and the measurement. However, overall this change would worsen the simulation for the following period (after the cut). For example, if a constant value of $R_{\text {litt_transf }}$ fixed at $3800 \mathrm{~s} \mathrm{~m}^{-1}$ were used, the simulated flux would be five time smaller than the measurements after the cut.

It should also be noted that, the simulation with the scenario $\mathrm{S} 1$ does not reproduce the emission after fertilization on 5 June, since measured soil $\left[\mathrm{NH}_{4}^{+}\right]$only increased on 6-7 June. This may reflect sampling uncertainty, linked also with soil sampling depth over the layer $0-10 \mathrm{~cm}$, with some days being required to reduce a strong $\left[\mathrm{NH}_{4}^{+}\right]$gradient near the soil surface, allowing the soil measurements in the layer 0 $10 \mathrm{~cm}$ to become more representative of surface conditions. For the days after the 9 June, the total simulated $\mathrm{NH}_{3}$ flux is again too high, suggesting again a necessary calibration of the soil or litter resistances or a questioning of the soil emission potential.

Bearing in mind that $\Gamma_{s}$ and $\Gamma_{\text {litter }}$ were prescribed, the model with the litter scenario agrees closely with the measurements over a period which shows a changes across two order of magnitude of the $\mathrm{NH}_{3}$ flux (Fig. 6). The only hypotheses made were that the litter had an constant additional resistance $R_{\text {litt_int }}=5000 \mathrm{~s} \mathrm{~m}^{-1}$ of the order of closed stomata (Jones, 1992; Weyers and Meidner, 1990), and that the bulk solution of the leaves was in equilibrium with the atmosphere, i.e. that the $\mathrm{NH}_{4}^{+}$measured in the bulk extracts is 
freely available, and that the bulk $\mathrm{pH}$ is representative of that solution..

In detail, the litter emission scenario tends to overestimates the $\mathrm{NH}_{3}$ fluxes following the cut (by 20\%). This overestimation might be due to (i) the exchange process at the litter being not a perfect equilibrium as expressed in Eq. (9), (ii) the $\Gamma_{\text {litter }}$ being overestimated by the extraction technique, (iii) the soil surface temperature being overestimated by the model during that period, (iv) an underestimation of the litter resistance, (v) the progressive transfer of the ammonium from the litter to the soil, or (vi) the cuticular exchange which could be higher than modelled in this study. Although all these hypotheses are plausible, they can not be proven with the available data.

In summary only two periods really fail with the simulation S2, from 30 May to 1 June, and from 8 to 10 June, which were among the hottest days of the experiment. For these periods just after the cut, the high overestimation of the model from 30 May to 1 June could be explained by the hay laying the ground surface, leading to a radiative and convective protection of the litter and a cooling of the ground surface due to the evaporation of the cut grass. The model did not represent well the surface temperature at this time (gap between measured and modelled temperature exceeding $10^{\circ} \mathrm{C}$ in the middle of the day), and so overestimated the $\mathrm{NH}_{3}$ litter emission. For the period on 8-10 June, the drying of the litter tissues probably leads to an immobilization of $\mathrm{NH}_{4}^{+}$, decreasing the $\mathrm{NH}_{4}^{+}$availability for volatilization.

Scenario S1, can be considered the least realistic interpretation, especially, as it does not take into account the processes of adsorption on the dry soil porous medium and/or the effective/freely $\mathrm{NH}_{4}^{+}$availability in the wet soil. The soil itself probably does contribute to the ground emission, but in a lesser extent than the litter, given the higher values of $\Gamma_{\text {litter }}$ than $\Gamma_{\text {soil }}$. It is concluded that the main source of $\mathrm{NH}_{3}$ emission prior to fertilization is the litter, with uncertainty dependent on the reliability of the measured values of $\Gamma_{\text {litter }}$.

\subsection{Partition of $\mathrm{NH}_{3}$ fluxes between the ground and the vegetation}

The close agreement between simulation S2 and the measurements allows investigation of the flux partitioning. Based on this model, the dynamics of this partitioning are summarized in Fig. 7, while a summary for day/night for the three main experimental periods is reported by Sutton et al. (2009b).

Before the cut. The good agreement at the transition from uncut to cut grassland, given the large values of $\Gamma_{\text {litter }}$ (Fig. 3) shows that before the cut the vegetation is, in general, absorbing all the $\mathrm{NH}_{3}$ emitted from the ground (Fig. 7). The model shows that between 5 and $20 \mathrm{ng} \mathrm{NH}_{3} \mathrm{~m}^{-2} \mathrm{~s}^{-1}$ are emitted from the ground before the cut, but that the flux above the canopy is a mean deposition flux of $-5 \mathrm{ng} \mathrm{NH}_{3} \mathrm{~m}^{-2} \mathrm{~s}^{-1}$ due to vegetation absorption (Fig. 7). However, the ground
$\mathrm{NH}_{3}$ emissions still have a great impact on the overall $\mathrm{NH}_{3}$ exchange by increasing the $\mathrm{NH}_{3}$ concentration around the leaves. Based on the model, if there was no source at the ground before the cut, the $\mathrm{NH}_{3}$ flux within the canopy would be a deposition flux of 5 to $40 \mathrm{ng} \mathrm{NH}_{3} \mathrm{~m}^{-2} \mathrm{~s}^{-1}$.

After the cut. There is some discussion in the literature about whether the cut would increase the stomatal compensation point as a result of remobilisation (Riedo et al., 2002; David et al., 2009b). However, Loubet et al. (2002) found no increase in $\Gamma_{s}$ immediately following the cut, but a slight increase later. Moreover the levels of $\Gamma_{s}$ in Loubet et al. (2002) were comparable to the $\Gamma_{s}$ found in this study and they can not explain the levels of emissions found after the cut. The increased $\mathrm{NH}_{3}$ emissions following the cut can be explained by two factors: (i) the magnitude of the stomatal and non-stomatal leaf surface sink is reduced by the cut, and (ii) the temperature of the litter changes from a daily mean of $15 \pm 10^{\circ} \mathrm{C}$ before the cut to a daily mean of $20 \pm 15^{\circ} \mathrm{C}$ after the cut (Fig. 5). Bearing in mind that a $5^{\circ} \mathrm{C}$ increase of the surface emitting $\mathrm{NH}_{3}$ induces a twofold increase in emissions (Eq. 9), this means that following the cut, the maximum emission from the litter is multiplied by 8 , which is what is observed in Fig. 7.

After the fertilisation. The fertilisation induces an increase of the $\mathrm{NH}_{3}$ fluxes which is well reproduced by the model (Fig. 6) due to the $\Gamma_{\text {litter }}$ increasing just following the application of fertiliser (and two days later $\Gamma_{\text {soil }}$ increases also). The nocturnal $\mathrm{NH}_{3}$ emissions between the 5 and the 6 June and the 6 and the 7 June are typical of non-stomatal emissions and are well reproduces by the litter emission scenario. In comparison, the soil emission scenario gives deposition $\mathrm{NH}_{3}$ fluxes the 5 and 6 June, which shows that $\chi_{z 0}<\chi_{a}\left(z_{\text {ref }}\right)$ (Fig. 1), hence demonstrating that the soil emission scenario ( $\Gamma_{\text {soil }}$, and $R_{\text {litt_transf }}$ ) fails to reproduce the emissions with the observed increase of $\mathrm{NH}_{3}$ concentration. Hence the simulations shown in Fig. 6 suggest that the main source following fertilisation is the litter which has effectively received the ammonium-nitrate pellets, and which contain the water (due to condensation) necessary for dissolving these pellets. However, the overestimation of the litter scenario in the following days ( 8 to 10 June) is still unclear. It might be due to (i) the litter resistance $R_{\text {litt_int }}$ changing as $\mathrm{NH}_{4}^{+}$becomes mixed into the litter, or (ii) $\mathrm{NH}_{4}^{+}$being not freely available due to metabolic changes.

\section{Conclusions}

The energy balance model presented in this study is shown to be adapted for modelling the latent and sensible heat fluxes over a grassland successively cut and fertilised, based on the prescription of measured canopy height and leaf area index. The model also succeeds in simulating the leaf and ground surfaces temperatures, except for few days during which the cut grass lay on the ground before lifting. 


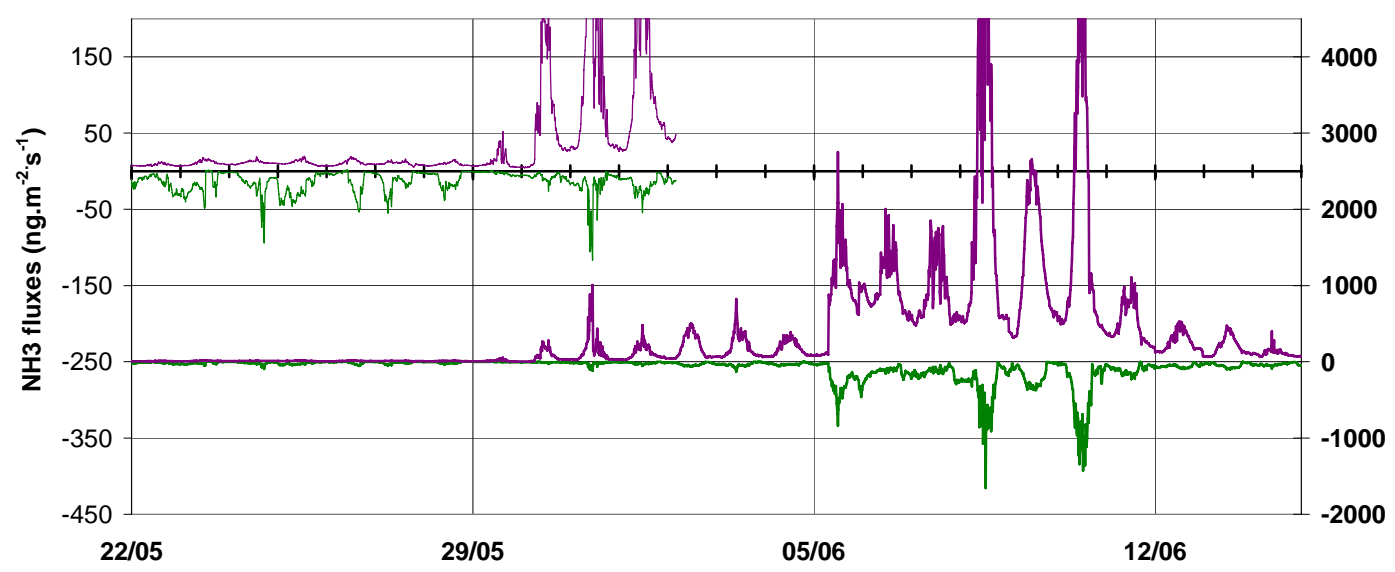

Fig. 7. Partitioning of the fluxes between the ground and the vegetation, for the litter scenario $S 2$, showing the flux with the litter (purple line) and the flux with the vegetation canopy (stomatal absorption plus cuticular deposition, green line). Note that there are two y-axis in order to magnify the period 21 May to 31 May (left y-axis), whereas the right axis applies for following period.

The overall agreement between the energy balance model and the measurements implies that the stomatal resistance is modelled reliably. The close simulations of temperature and stomatal resistance thus validate the coupling between the energy balance model and the $\mathrm{NH}_{3}$ exchange model, since $\mathrm{NH}_{3}$ exchange is mainly influenced by the stomatal resistance and the surface concentration, which is exponentially linked to temperature.

Using measured emission potentials of the apoplasm and litter, the $\mathrm{NH}_{3}$ exchange model successfully simulates the measured $\mathrm{NH}_{3}$ fluxes during the cut and fertilisation period, over which the fluxes change by two orders of magnitude. The analysis of the partitioning of the fluxes between the model compartments, especially before and after the cut shows that the grassland can be described by the litter surface source, together with a stomatal sink during the day and a leaf cuticle sink at night (cf. Sutton et al., 2009b).

Of the different compensation points simulated, i.e. for green leaves, litter and the soil surface, the classical role of a foliar compensation point is rather different in the present study. Here, instead of the net flux depending on the balance of the air concentration and the foliar (stomatal) compensation point, the overall canopy compensation point and net fluxes are influenced to a large degree by emission potentials from the leaf litter. Prior to the cut, these emissions are mostly recaptured by the overlaying canopy, while they dominate net emissions following cutting and fertilization. Future work should thus pay more attention to the dynamics of nitrogen cycling with conditions at the litter and soil surface.

The agreement between the modelled and measured $\mathrm{NH}_{3}$ fluxes hence demonstrate (i) the necessity to consider two layers (stomata and litter/soil surface), (ii) the need to couple with an energy balance model which can simulate the leaf and litter/soil surface temperature, and (iii) the interests in us- ing $\mathrm{NH}_{3}$ emissions potentials in the litter and the apoplasm, which can be measured in the field.

The latter point also indicates a limitation of this model, which needs the emissions potentials of the apoplast and litter to be prescribed, as well as the canopy height and leaf area index. This emphasises the need to improve our understanding of the seasonal pattern of these emissions potentials, which implies a better understanding of the ammonium metabolism and $\mathrm{pH}$ regulation in both live and decaying leaves.

Overall, the performance of the coupled model SURFATM- $\mathrm{NH}_{3}$ provides a basis that is also suited to other gaseous compounds. This model thus provides a simplified generalised approach for wider application atmospheric transport models.

\section{Appendix A}

\section{Description of the energy balance model}

Radiation, heat and vapour transfer. The net absorption of radiation by the vegetation and the soil $R n_{T}$ is given by (Varlet-Grancher, et al. 1989; Tuzet and Perrier, 1992):

$$
\begin{aligned}
& R n_{T}=R n_{\text {veg }}+R n_{\text {soil }} \\
& R n_{\text {veg }}=R n_{T} \cdot \exp \left(-k_{R n} . \mathrm{LAI}\right)
\end{aligned}
$$

The energy received by the leaves is partitioned between latent and sensible heat components, while at the soil surface an additional conduction heat flux is included:

$$
\begin{aligned}
& R n_{\mathrm{veg}}=H_{\mathrm{veg}}+\lambda E_{\mathrm{veg}} \\
& R n_{\text {soil }}=H_{\text {soil }}+\lambda E_{\text {soil }}+G
\end{aligned}
$$


Table C1. Parameterisations used in the stomatal resistance model. All conductances are in $\mathrm{m} \mathrm{s}^{-1}$. PAR is the photosynthetically active radiation in $\left(\mu \mathrm{mol} \mathrm{m}{ }^{-2} \mathrm{~s}^{-1}\right)$, VPD is the leaf-to-air vapour pressure deficit $(\mathrm{kPa}), T_{z 0^{\prime}}$ is the canopy temperature $\left({ }^{\circ} \mathrm{C}\right), \mathrm{SWP}$ is the soil water potential $(\mathrm{MPa})$.

\begin{tabular}{|c|c|c|}
\hline Name & Parameterisation & Comments units \\
\hline$g_{\max }$ & $0.0115\left(\mathrm{~m} \mathrm{~s}^{-1}\right)$ & identical to $468 \mathrm{mmol} \mathrm{H}_{2} \mathrm{O} \mathrm{m}^{-2} \mathrm{~s}^{-1}$ \\
\hline$g_{\text {PAR }}$ & $\{1-\exp (-0.009 . \mathrm{PAR})\}$ & PAR in $\mu \mathrm{mol} \mathrm{m}^{-2} \mathrm{~s}^{-1}$ \\
\hline$g_{\mathrm{VPD}}$ & $\begin{array}{l}\text { If } \mathrm{VPD}>3 \text { then } g_{\mathrm{VPD}}=0 \\
\text { If } \mathrm{VPD}<1.3 \text { then } g_{\mathrm{VPD}}=1 \\
\text { If } 1.3<\mathrm{VPD}<3 \text { then } g_{\mathrm{VPD}}=-\frac{\mathrm{VPD}}{1.7}+1.76\end{array}$ & VPD in $\mathrm{kPa}$ \\
\hline$g_{T}$ & $\begin{array}{l}g_{T}=1-\left[\frac{T_{z 0^{\prime}}-T_{\mathrm{opt}}}{T_{\mathrm{opt}}-T_{\mathrm{min}}}\right]^{2} \text {, with } T_{\mathrm{opt}}=26^{\circ} \mathrm{C}, T_{\min }=12^{\circ} \mathrm{C} \text { and } T_{\max }=40^{\circ} \mathrm{C} \text {. } \\
\text { The function is symmetrical, such that the maximum of temperature } \\
\left(T_{\max }\right) \text { is used in this equation. }\end{array}$ & $\begin{array}{l}T_{\mathrm{Opt}} \text { is the temperature of maximum con- } \\
\text { ductance, } T_{\min } \text { (or } T_{\max } \text { ) is the temper- } \\
\text { ature at which the conductance falls to } \\
\text { zero. }\end{array}$ \\
\hline$g_{\text {SWP }}^{\mathrm{a}}$ & $\begin{array}{l}\text { If } \mathrm{SWP}>-0.49 \text { then } g_{\mathrm{SWP}}=1 \\
\text { If } \mathrm{SWP}<-1.5 \text { then } g_{\mathrm{SWP}}=0 \\
\text { If }-1.5<\mathrm{SWP}<-0.49 \text {, then } g_{\mathrm{VPD}}=\frac{\mathrm{SWP}}{1.01}+1.49\end{array}$ & SWP is the soil water potential in MPa. \\
\hline
\end{tabular}

a The pedotransfer function of Carsel and Parrish (1988) is used to extrapolate soil water moisture to soil water potential.

The total heat flux $H_{T}$, and the total latent heat flux $\lambda E_{T}$ are calculated as:

$$
\begin{aligned}
& H_{T}=\rho_{a} \cdot c p_{a} \cdot \frac{T_{a}\left(z_{\mathrm{ref}}\right)-T_{z 0}}{R_{a(\mathrm{air})}} H_{T}=\rho_{a} \cdot c_{p} \cdot \frac{T_{a}-T_{z 0}}{R_{a}} \\
& \lambda E_{T}=\frac{\rho_{a} \cdot c p_{a}}{\gamma} \cdot \frac{e_{a}\left(z_{\mathrm{ref}}\right)-e_{z 0}}{R_{a}\left(z_{\mathrm{ref}}\right)} \lambda E_{T}=\frac{\rho_{a} \cdot c_{p}}{\gamma} \cdot \frac{e_{a}-e_{z 0}}{R_{a}}
\end{aligned}
$$

In the canopy, the flux partition is given by:

$$
\begin{aligned}
H_{\mathrm{veg}} & =\rho_{a} \cdot c_{p} \cdot \frac{T_{z 0}-T_{z 0^{\prime}}}{R_{b f}^{H}} \\
\lambda E_{\mathrm{veg}} & =\frac{\rho_{a} \cdot c p_{a}}{\gamma} \cdot \frac{e_{z 0}-e_{z 0^{\prime}}}{R_{b f}^{W}}=\frac{\rho_{a} \cdot c p_{a}}{\gamma} \cdot \frac{e_{z 0}-e_{s}^{*}}{R_{b f}^{W}+R_{s f}^{W}} \lambda E_{\mathrm{veg}} \\
& =\frac{\rho_{a} \cdot c_{p}}{\gamma} \cdot \frac{e_{z 0}-e_{z 0^{\prime}}}{R_{b f}^{W}}=\frac{\rho_{a} \cdot c_{p}}{\gamma} \cdot \frac{e_{z 0}-e_{s}^{*}}{R_{b f}^{W}+R_{s f}^{W}}
\end{aligned}
$$

At the soil surface, the heat fluxes are given by:

$$
\begin{aligned}
H_{s} & =\rho_{a} \cdot c_{p} \cdot \frac{T_{z 0}-T_{\text {surf }}}{R_{\mathrm{bss}}^{H}+R_{a c}} \\
\lambda E_{s} & =\frac{\rho_{a} \cdot c p_{a}}{\gamma} \cdot \frac{e_{z 0}-e_{\text {surf }}}{R_{b s s}^{W}+R_{a c}} \\
& =\frac{\rho_{a} \cdot c p_{a}}{\gamma} \cdot \frac{e_{z 0}-e_{\text {soil }}^{*}}{R_{b s s}^{W}+R_{a c}+R_{\text {dry_soil }}^{W}} \lambda E_{s} \\
& =\frac{\rho_{a} \cdot c_{p}}{\gamma} \cdot \frac{e_{z 0}-e_{\text {surf }}}{R_{b s s}^{W}+R_{a c}} \\
& =\frac{\rho_{a} \cdot c_{p}}{\gamma} \cdot \frac{e_{z 0}-e_{\text {soil }}^{*}}{R_{b s s}^{W}+R_{a c}+R_{\text {dry_soil }}^{W}}
\end{aligned}
$$

$$
G=\lambda_{\text {wet }} \cdot \frac{T_{\text {bot }}-T_{\text {soil }}}{\Delta_{\text {wet }}}=\rho_{a} \cdot c_{p} \cdot \frac{T_{\text {bot }}-T_{\text {soil }}}{R_{\text {wet_soil }}^{H}}
$$

As in Choudhury and Monteith (1988), the volumetric heat capacity for air in Eq. (A11) appears for algebraic convenience $\left(\lambda_{\text {wet }}\right.$ is the thermal conductivity extending from the soil bottom to the soil wet-dry boundary, over a thickness $\left.\Delta_{\text {wet }}\right)$. The resolution of the energy budget, which involves iterations to account for buoyancy, is performed with the method proposed by Choudhury and Monteith (1988).

\section{Appendix B}

\section{Details of the aerodynamic resistances}

Aerodynamic resistance above the canopy. The aerodynamic resistance for scalar above the canopy $\left(R_{a}\right)$, at height $z_{\text {ref }}$, is calculated as:

$R_{a}=\frac{1}{\kappa^{2} \cdot u(Z)} \cdot\left\{\ln \left[\frac{Z}{z_{0}}\right]-\psi_{H}(Z / L)\right\}$

where $\kappa$ is the von-kàrmàn constant $(0.4), Z=z_{\text {ref }}-d, d$ being the displacement height, $u(Z)$ is the wind speed, $z_{0}$ is the canopy roughness height, $L$ is the Monin-Obukhov length, and $\Psi_{H}$ and $\Psi_{M}$ are the stability correction functions for heat and momentum, respectively. The correction functions of Dyers and Hicks (1970) are used.

Aerodynamic resistance inside the canopy. Considering that the foliage has a homogeneous vertically distribution, the windspeed decreases exponentially (Cowan, 1965):

$$
\begin{aligned}
& u(z)=u\left(h_{c}\right) \cdot \exp \left[\alpha_{u} \cdot\left(\frac{z}{h_{c}}-1\right)\right] \\
& u(z)=u\left(h_{c}\right) \cdot \exp \left[\alpha_{u} \cdot\left(\frac{z}{h_{c}}-1\right)\right]
\end{aligned}
$$


with $u(z)$, the wind speed inside the canopy at height $z, u\left(h_{c}\right)$ the wind speed at the canopy height $\left(h_{c}\right), \alpha_{u}$ is the attenuation coefficient for the decrease of the wind speed inside the cover (Raupach et al., 1996). With the hypothesis that the decrease of the diffusivity is proportional to the decrease of the wind speed inside the canopy, the aerodynamic resistance inside the cover $\left(R_{a c}\right)$ takes the form:

$R_{a c}=\frac{h_{c} \cdot \exp \left(\alpha_{u}\right)}{\alpha_{w} \cdot K_{M}\left(h_{c}\right)} \cdot\left\{\exp \left(-\alpha_{u} \cdot z_{0 s} \cdot h_{c}\right)-\exp \left(\frac{-\alpha_{u}\left(d+z_{0}\right)}{h_{c}}\right)\right\}$

where $K_{M}\left(h_{c}\right)$ is the eddy diffusivity coefficient at canopy height $h_{c}$, and $z_{0 s}$ is the ground surface roughness length.

For more exact analysis, some corrections can be integrated if standard deviation of the vertical wind speed can be measured or modelled (Raupach, 1989).

\section{Appendix C}

\section{Details of the stomatal resistance model}

Following Emberson et al. (2000), the stomatal conductance for the gas $i g_{s}^{i}$ per leaf are is calculated as:

$g_{s}^{i}=\frac{D_{i}}{D_{w}}\left\{g_{\max } \cdot \max \left(g_{\min }, g_{T} \cdot g_{\mathrm{PAR}} \cdot g_{\mathrm{VPD}} \cdot g_{\mathrm{SWP}}\right)\right\}$

where $D_{i}$ and $D_{w}$ are the molecular diffusivities of the gas $i$ and of water vapour in air, respectively; $g_{\max }$ denotes the maximum stomatal conductance allowed for a certain species by the model and $g_{\min }$ the minimum daytime stomatal conductance observed under field condition. The factors $g_{T}$, $g_{\text {PAR }}$ and $g_{\mathrm{VPD}}$ represent the short-term effects of leaf temperature, photosynthetically active radiation, and leaf-to-air vapour pressure difference. The effect of soil water potential is reflected by the $g_{\mathrm{SWP}}$ factor. Although at very high concentrations $\mathrm{NH}_{3}$ can have an effect on stomata aperture (van Hove et al., 1989), at normal ambient concentrations this effect is expected to be minimal. So, no effect of ammonia on $g_{s}^{i}$ is included in the present implementation of the model. As the fluxes from foliage surface integrate the exchanges from the individual leaves, the canopy stomatal resistance for water is estimated according the approach of Zhou et al. (2006),

$R_{s}^{W}=\frac{\left(\overline{g_{s}}\right)^{-1}}{\mathrm{LAI}_{\mathrm{eff}}}$

integrating an effective leaf area index which combines the status of the different leaf populations.

Acknowledgements. The authors gratefully acknowledge funding of this work by under the European Commission GRAMINAE project, together with funds from INRA and AgroParisTech and the UK Department for Environment, Food and Rural Affairs (Air Quality Research Programme). Final synthesis of this work was conducted under the frame of the EC integrated project NitroEurope and completed with support of the ACCENT Network of Excellence.

Edited by: K. Pilegaard

\section{References}

Anderson, N., Strader, R., and Davidson, C.: Airborne reduced nitrogen: ammonia emissions from agriculture and other sources, Environ. International, 29, 277-286, 2003.

Bates, R. G. and Pinching, G. D.: Dissociation constant of aqueous ammonia at 0 to $50^{\circ} \mathrm{C}$ from m.f studies of the ammonium salt of a weak acid, Am. Chem. Soc. J., 72, 1393-1396, 1950.

Bobbink, R.: Effect of nutrient enrichment in Dutch chalk grassland, J. Appl. Ecol., 28, 28-41, 1991.

Bouwman, A. F., Lee, D. S., Asman, W. A. H., Dentener, F. J., and van der Hoek, K. W.: A global high-resolution emission inventory for ammonia, Global Biogeochem. Cycles, 11, 561-587, 1997.

Burkhardt, J., Flechard, C. R., Gresens, F., Mattsson, M., Jongejan, P. A. C., Erisman, J. W., Weidinger, T., Meszaros, R., Nemitz, E., and Sutton, M. A.: Modelling the dynamic chemical interactions of atmospheric ammonia with leaf surface wetness in a managed grassland canopy, Biogeosciences, 6, 67-83, 2009, http://www.biogeosciences.net/6/67/2009/.

Carsel, R. F. and Parrish, R. S.: Developping joint probablility distributions of soil water retention characteristics, Water Resour Res., 24, 755-769, 1988.

Choudhury, B. J. and Monteith, J. L.: A four-layer model for the heat budget of homogeneous land surfaces, Q. J. Roy. Meteorol. Soc., 114, 373-398, 1988.

Cowan, I. R.: Transport of water in soil plant atmosphere system, J. Appl. Ecol., 2, 221-239, 1965.

David, M., Loubet, B., Cellier, P., Mattsson, M., Schjoerring, J. K., Nemitz, E., Roche, R., Riedo, M., and Sutton, M. A.: Ammonia sources and sinks in an intensively managed grassland using dynamic chambers, Biogeosciences Discuss., 6, 1625-1655, 2009a, http://www.biogeosciences-discuss.net/6/1625/2009/.

David, M., Roche, R., Mattsson, M., Sutton, M. A., Dämmgen, U., Schjoerring, J. K., and Cellier, P.: The effects of management on ammonia fluxes over a cut grassland as measured by use of dynamic chambers, Biogeosciences Discuss., 6, 1599-1623, 2009b, http://www.biogeosciences-discuss.net/6/1599/2009/.

Dragosits, U., Theobald, M. R., Place, C. J., Lord, E., Webb, J., Hill, J., ApSimon, H. M., and Sutton, M. A.: Ammonia, emission, deposition and impact assessments at the field scale: a case of study of sub-grid spatial variability, Environ. Pollut., 1, 147-158, 2002.

Dyers, A. G. and Hicks, B. B.: Flux-profile relationship in the constant flux layer, Q. J. Roy. Meteorol. Soc., 96, 715-721, 1970.

Emberson, L. D., Simpson, D., Tuovinen, J.-P., Ashmore, M. R., and Cambridge, M. H.: Towards a model of ozone deposition and stomatal uptake avore Europe. EMEP/MSC - W Note 6/2000. Norwegian Meteorological Institute, Oslo, http://www.emep.int/ publ/reports/2000/dnmi_note_6_2000.pdf, 2000.

Erisman, J. W. and Wyers, G. P.: Continuous measurements of surface exchange of $\mathrm{SO}_{2}$ and $\mathrm{NH}_{3}$ : implications for their possible interaction in the deposition process, Atmos. Environ., 27, 1937 1949, 1993.

Fangmeier, A., Hadwiger-Fangmeier, A., Van der Eerden, L., and Jäger, H. J.: Effects of atmospheric ammonia on vegetation - a review, Environ. Pollut., 86, 43-82, 1994.

Farquhar, G. D., Firth, P. M., Wetselaar, R., and Wier, B.: On the gaseous exchange of ammonia between leaves and the environment: determination of the ammonia compensation point, Plant 
Physiol., 66, 710-714, 1980.

Flechard, C., Fowler, D., Sutton, M. A., and Cape, J. N.: Modelling of ammonia and sulphur dioxide exchange over moorland vegetation, Q. J. Roy. Meteorol. Soc., 125, 2611-2641, 1999.

Fowler, D., Cape, J. N., and Unsworth, M. H.: Deposition of atmospheric pollutants on forest, Phil. Trans. Roy. Soc. London B., 324, 247-265, 1989.

Freibauer, A.: Regionalised inventory of biogenic greenhouse gas emissions from European agriculture, Eur. J. Agron., 19, 153160,2003

Ganzeveld, L. N., Lelieveld, J., Dentener, F. J., Krol, M. C., and Roelofs, G.-J.: Atmosphere-biosphere trace gas exchanges simulated with a single-column model, J. Geophys. Res., 107(D16), 4297, doi:10.1029/2001JD000684, 2002.

Genermont, S., Cellier, P., Flura, D., Morvan, T., and Laville, P.: Measuring ammonia fluxes after slurry spreading under actual field conditions, Atmos. Environ., 32, 279-284, 1998.

Grünhage, L. and Haenel, H-D.: PLATIN (PLant-ATmosphereInteraction) I : A model of plant-atmosphere interaction for estimating absorbed doses of gaseous air pollutants, Environ. Pollut., 98, 37-50, 1997.

Guyot G.: Physics of the environment and climate, John Wiley, Chichester, 632 pp., 1998.

Hensen, A., Nemitz, E., Flynn, M. J., Blatter, A., Jones, S. K., Sørensen, L. L., Hensen, B., Pryor, S., Jensen, B., Otjes, R. P., Cobussen, J., Loubet, B., Erisman, J. W., Gallagher, M. W., Neftel, A., and Sutton, M. A.: Inter-comparison of ammonia fluxes obtained using the relaxed eddy accumulation technique, Biogeosciences Discuss., 5, 3965-4000, 2008, http://www.biogeosciences-discuss.net/5/3965/2008/.

Herrmann, B., Mattsson, M., Jones, S. K., Cellier, P., Milford, C., Sutton, M. A., Schjoerring, J. K., and Neftel, A.: Vertical structure and diurnal variability of ammonia exchange potential within an intensively managed grass canopy, Biogeosciences, 6 , 15-23, 2009, http://www.biogeosciences.net/6/15/2009/.

Hicks, B. B., Baldocchi, D. D., Meyers, T. P., Hosker Jr., R. P., and Matt, D. R.: A preliminary multiple resistance routine for deriving dry deposition velocities from measured quantities, Water Air Soil Pollut., 36, 311-330, 1987.

Husted, S. and Schjorerring, J. K.: Apoplastic pH and ammonium concentration in leaves of Brassica napus L., Plant Physiol., 109, 1453-1460, 1995.

Husted S., Schjorerring, J. K., Nielsen, K. H., Nemitz, E., and Sutton, M. A.: Stomatal compensation points for ammonia in oilseed rape plants under field conditions, Agr. Forest. Meteorol., 105, 371-383, 2000.

Hyde, B. P., Carton, O. T., O'Toole, P., and Misselbrook, T. H.: A new inventory of ammonia emissions from Irish agriculture, Atmosph. Environ., 37, 55-62, 2003.

Jarvis, P. G.,: The interpretation of the variation in leaf water potential and stomatal conductance found in canopies in the field, Phil. Trans. Roy. Soc. London. (B), 273, 375-391, 1976.

Jones H. G.: Plants and Microclimate. A quantitative approach to environnemental plant physiology, Cambridge University Press, 428 pp., 1992.

Krupa, S. V.: Effects of ammonia (NH3) on terrestrial vegetation : a review, Environ. Pollut., 124, 179-221, 2003.

Li, C., Zhuang, Y., Cao, M., Crill, P., Frolking, S., Moore, B., Salas, W., Song, W., and Wang, X.: Comparing a process-based agro- system model to the IPCC methodology for developing a national inventory of $\mathrm{N}_{2} \mathrm{O}$ emissions from arable lands in China, Nutrient Cycling Agrosystems, 60, 159-175, 2001.

Loubet, B.: Modélisation du dépôt sec d'ammoniac atmosphérique à proximité des sources, PhD Thésis, 329 pp., Paul Sabatier University, Toulouse, France, 2000.

Loubet, B., Milford, C., Sutton, M. A., and Cellier, P.: Investigation of the interactions between sources and sinks of atmospheric ammonia in an upland landscape using a simplified dispersion exchange, J. Geophys. Res., 106(D20), 24183-24195, 2001.

Loubet, B., Milford, C., Hill, P. W., Tang, Y. S., Cellier, P., and Sutton, M. A.: Seasonal variability of apoplastic $\mathrm{NH} 4+$ and $\mathrm{pH}$ in an intensively managed grassland, Plant Soil, 238, 97-110, 2002.

Loubet, B., Cellier, P., Milford, C., and Sutton, M. A.: A coupled dispersion and exchange model for short-range dry deposition of atmospheric ammonia, Q. J. Roy. Meteorol. Soc., 132, 17331763, doi:10.1256/qj.05.73, 2006.

Loubet, B., Milford, C., Hensen, A., Daemmgen, U., Erisman, J.W., Cellier, P., and Sutton, M. A.: Advection of NH3 over a pasture field, and its effect on gradient flux measurements, Biogeosciences Discuss., 6, 163-196, 2009, http://www.biogeosciences-discuss.net/6/163/2009/.

Lumley, J. L. and Panofsky, H. A.: The structure of Atmospheric Turbulence. Wiley-Interscience, New York, 239 pp., 1964.

Massman, W. J.: A review of the molecular diffusivities of $\mathrm{H}_{2} \mathrm{O}$, $\mathrm{CO}_{2}, \mathrm{CH}_{4}, \mathrm{CO}, \mathrm{O}_{3}, \mathrm{SO}_{2}, \mathrm{NH}_{3}, \mathrm{~N}_{2} \mathrm{O}, \mathrm{NO}$ and $\mathrm{NO}_{2}$ in air, $\mathrm{O}_{2}$ and $\mathrm{N}_{2}$ near STP, Atmos. Environ., 32, 1111-1127, 1998.

Mattsson, M. and Schjoerring, J. K.: Dynamic and steady-state responses of inorganic nitrogen pools and $\mathrm{NH} 3$ exchange in leaves of Lolium perenne and Bromus erectus to changes in root nitrogen supply, Plant Physiol., 128, 742-750, 2002.

Mattsson, M. and Schjoerring, J. K.: Senescence-induced changes in apoplastic and bulk tissue ammonia concentrations of ryegrass leaves, New Phytol., 160, 489-499, 2003.

Mattsson, M., Herrmann, B., David, M., Loubet, B., Riedo, M., Theobald, M. R., Sutton, M. A., Bruhn, D., Neftel, A., and Schjoerring, J. K.: Temporal variability in bioassays of the stomatal ammonia compensation point in relation to plant and soil nitrogen parameters in intensively managed grassland, Biogeosciences, 6, 171-179, 2009a, http://www.biogeosciences.net/6/171/2009/.

Mattsson, M., Herrmann, B., Jones, S., Neftel, A., Sutton, M. A., and Schjoerring, J. K.: Contribution of different grass species to plant-atmosphere ammonia exchange in intensively managed grassland, Biogeosciences, 6, 59-66, 2009b, http://www.biogeosciences.net/6/59/2009/.

Milford, C., Theobald, M. R., Nemitz, E., and Sutton, M. A.: Dynamics of ammonia exchange in response to cutting and fertilizing in an intensively-managed grassland, Water Air Soil Pollut., Focus, 1, 167-176, 2001a.

Milford, C., Theobald, M. R., Nemitz, E., and Sutton, M. A.: Dynamics of ammonia exchange in response to cutting and fertilising in an intensively-managed grassland, in: Air-Surface Exchange of Gases and Particles (2000), edited by: Fowler, D., Pitcairn, C. E. R., and Erisman, J.-W., Kluwer, Academic Publishers, 2001b.

Milford, C., Theobald, M. R., Nemitz, E., Hargreaves, K. J., Horvath, L., Raso, J., Dämmgen, U., Neftel, A., Jones, S. K., 
Hensen, A., Loubet, B., Cellier, P., and Sutton, M. A.: Ammonia fluxes in relation to cutting and fertilization of an intensively managed grassland derived from an inter-comparison of gradient measurements, Biogeosciences, 6, 819-834, 2009,

http://www.biogeosciences.net/6/819/2009/.

Monteith, J. L. and Unsworth, M. H.: Principles of environmental physics, 2nd edn., Arnold Press, London, 291 pp, 1990.

Nemitz, E., Sutton, M. A., Gut, A., San Jose, R., Husted, S., and Schjørring, J. K.: Sources and sinks of ammonia within an oilseed rape canopy, Agric. Forest Meteorol., 105, 385-404, 2000a.

Nemitz, E., Sutton, M. A., Schjoerring, J. K., Husted, S., and Wyers, G. P.: Resistance modelling of ammonia exchange over oilseed rape, Agric. Forest Meteorol., 105, 405-425, 2000 b.

Nemitz, E., Milford, C., and Sutton, M. A.: A two-layer canopy compensation point model for describing bi-directional biosphere/atmosphere exchange of ammonia, Q. J. Roy. Meteorol. Soc., 127, 815-833, 2001.

Nemitz, E., Hargreaves, K. J., Neftel, A., Loubet, B., Cellier, P., Dorsey, J. R., Flynn, M., Hensen, A., Weidinger, T., Meszaros, R., Horvath, L., Dämmgen, U., Frühauf, C., Lpmeier, F. J., Gallagher, M. W., and Sutton, M. A.: Intercomparison and assessment of turbulent and physiological exchange parameters of grassland, Biogeosciences Discuss., 6, 241-290, 2009, http://www.biogeosciences-discuss.net/6/241/2009/.

Nikolov, N. and Zeller, K.: Modeling coupled interactions of carbon, water and ozone exchange terrestrial ecosystems and atmosphere. I: Model description, Environ. Pollut., 124, 231-246, 2003

Pinder, R. W., Pekney, N. J., Davidson, C. I., and Adams, P. J.: A process-based model of ammonia emissions from dairy cows: improved temporal and spatial resolution, Atmos. Environ., 38, 1357-1365, 2004.

Polcher, J., McAvaney, B., Viterbo, P., Gaertner, M.-A., Hahmann, A., Mahfouf, J.-F., Noilhan, J., Phillips, T., Pitman, A., Schlosser, C. A., Schulz, J.-P., Timbal, B., Verseghy, D., and Xue, Y.: A proposal for a general interface between land-surface schemes and general circulation models, Global Planet. Change, 19, 261-276, 1998.

Raupach, M. R.: Stand overstorey processes, Phil. Trans. Roy. Soc. London. (B), 324, 175-190, 1989.

Raupach, M. R., Finnigan, J. J., and Brunet, Y.: Coherent eddies and turbulence inside vegetation canopies. The mixing layer analogy, Bound. Lay. Meteorol., 78, 351-382, 1996.

Riedo, M., Milford, C., Schmid, M., and Sutton, M. A.: Coupling soil-plant-atmosphere exchange of ammonia with ecosystem functioning in grasslands, Ecological Modelling, 158, 83$110,2002$.

Schaap, M. G. and Bouten, W.: Forest floor in a dense Douglas fir stand, J. Hydrol., 193, 97-113, 1997.

Schjoerring, J. K.: Plant-atmosphere ammonia exchange: Quantification, physiology regulation and interaction with environmental factors, D. Sc. Thesis, Roy. Veterinary and Agric. Univ. Copenhage, Danemark, 55 pp, 1997.

Schjoerring, J. K., Husted, S., and Mattsson, M.: Physiological parameters controlling plant-atmosphere ammonia exchange, Atmos. Environ., 32, 491-498, 1998.

Schjoerring, J. K., Husted, S., Mack, G., Nielsen, K. H., Finnemann, J., and Mattsson, M.: Physiological regulation of plant- atmosphere ammonia exchange, Plant Soil, 221, 95-102, 2000.

Shuttelworth, W. J. and Wallace, S. J.: Evaporation from sparse crop - An energy combination theory, Q. J. Roy. Meteorol. Soc., 111, 477-507, 1985.

Stevens, C. J., Dise, N. B., Gowing, D. J. G., and Mountford, J. O.: Loss of forb diversity in relation to nitrogen deposition in the UK : regional trends and potential controls, Global Change Biol., 12, 1823-1833, 2006.

Stevens, C. J., Dise, N. B., Mountford, J. O., and Gowing, D. J. G.: impact of nitrogen deposition on the species richness of grasslands, Science, 303, 1876-1879, 2004.

Sutton, M. A., Pitcairn C. E., R., and Fowler, D.: The exchange of ammonia between the atmosphere and plant communities, Adv. Ecol. Res., 24, 301-389, 1993.

Sutton, M. A., Schjoerring, J. K., and Wyer, G. P.: Plant atmosphere exchange of ammonia. Phil. Trans. Roy. Soc. Lond. A., 351, 261-278, 1995.

Sutton, M. A., Burkardt, J. K., Guerin, D., Nemitz, E., and Fowler, D.: Development of resistance models to describe measurements of bi-directional ammonia surface atmosphere exchange, Atmos. Environ., 32, 473-480, 1998a.

Sutton, M. A., Milford, C., Dragosits, U., Place, C. J., Singles, R. J., Smith, R. I., Pitcairn, C. E. R., Fowler, D., Hill, J., ApSimon, H. M. , Ross, C., Hill, R., Jarvis, S. C., Pain, B. F., Phillips, V. C., Harrison, R., Moss, D., Webb, J., Espenhahn, S. E., Lee, D. S., Hornung, M., Ullyett, J., Bull, K. R., Emmett, B. A., Lowe, J., and Wyers., G. P.: Dispersion, deposition and impacts of atmospheric ammonia: quantifying local budgets and spatial variability, Environ. Pollut., 102, 349-361, 1998b.

Sutton, M. A., Milford, C., Nemitz, E., Theobald, M. R., Hill, P. W., Fowler, D., Schjoerring, J. K., Mattsson, M. E., Nielsen, K. H., Husted, S., Erisman, J. W., Otjes, R., Hensen, A., Mosquera, J., Cellier, P., Loubet, B., David, M., Genermont, S., Neftel, A., Blatter, A., Herrmann, B., Jones, S. K., Horvath, L., Führer, E., Mantzanas, K., Koukoura, Z., Gallagher, M., Williams, P., Flynn, M., and Riedo, M.: Biosphere-atmosphere interactions of ammonia with grasslands: experimental strategy and results from a new European initiative, Plant Soil, 228, 131-145, 2001.

Sutton, M. A., Nemitz, E., Erisman, J. W., Beier C., Butterbach Bahl, K., Cellier, P., de Vries, W., Cotrufo, F., Skiba, U., Di Marco, C., Jones, S., Laville, P., Soussana, J.-F., Loubet, B., Twigg, M., Famulari, D., Whitehead, J., Gallagher, M.W., Neftel, A., Flechard, C. R., Herrman, B., Calaca, P. L., Schjoerring, J. K., Daemmgen, U., Horvarth, L., Tang, Y. S., Emmett, B. A., Tietema, A., Penuelas, J., Kesik, M., Brueggemann, N., Pilegaard, K., Vesala, T., Campbell, C. L., Olesen, J. E., Dragosits, U., Theobald, M. R., Levy, P., Mobbs, D. C., Milne, R., Viovy, N., Vuichard, N., Smith, J. U., Smith, P., Bergamaschi, P., Fowler, D., and Reis, S.: Challenges in quantifying biosphereatmosphere exchange of nitrogen species, Environ. Pollut., 150, 125-139, 2007.

Sutton, M. A., Nemitz, E., Theobald, M. R., Milford, C., Dorsey, J. R., Gallagher, M. W., Hensen, A., Jongejan, P. A. C., Erisman, J. W., Mattsson, M., Schjoerring, J. K., Cellier, P., Loubet, B., Roche, R., Neftel, A., Hermann, B., Jones, S. K., Lehman, B. E., Horvath, L., Weidinger, T., Rajkai, K., Burkhardt, J., Löpmeier, F. J., and Daemmgen, U.: Dynamics of ammonia exchange with cut grassland: strategy and implementation of the GRAMINAE Integrated Experiment, Biogeosciences, 6, 309-331, 2009a, 
http://www.biogeosciences.net/6/309/2009/.

Sutton, M. A., Nemitz, E., Milford, C., Campbell, C., Erisman, J. W., Hensen, A., Cellier, P., David, M., Loubet, B., Personne, E., Schjoerring, J. K., Mattsson, M., Dorsey, J. R., Gallagher, M. W., Horvath, L., Weidinger, T., Meszaros, R., Dämmgen, U., Neftel, A., Herrmann, B., Lehman, B. E., Flechard, C., and Burkhardt, J.: Dynamics of ammonia exchange with cut grassland: synthesis of results and conclusions of the GRAMINAE Integrated Experiment, Biogeosciences Discuss., 6, 1121-1184, 2009b, http://www.biogeosciences-discuss.net/6/1121/2009/.

Theobald, M. R., Dragosits, U., Place, C. J., Smith, J. U., Sozanska, M. Brown, L., Scholefield, D., Del Prado, A., Webb, A., Whitehead, P. G., Angus, A., Hodge, I. D., Fowler, D., and Sutton, M. A.: Modelling nitrogen fluxes at the landscape scale, Water Air Soil Pollut., 6, 135-142, 2004.

Tulet, P., Crassier, V., and Rosset R.: Air pollution modelling at a regional scale, Environ. Modell. Softw., 15, 693-701, 2000.

Tuzet, A. and Perrier, A.: Crop water budget estimation of irrigation requirement, ICID Bulletin., 44, 1-16, 1992.

Tuzet, A., Perrier, A., and Oulid Aissa, A. K.: A prediction model for field drying of hay using a heat balance method, Agric. Forest Meteorol., 65, 63-89, 1993.

Twine, T. E., Kustas, W. P., Noman, J. M., Cook, D. R., Houser, P. R., Meyers, T. P., Prueger, J. H., Starks, P. J., and Wesely, M. L.: Correcting eddy-covariance flux underestimates over a grassland, Agric. Forest Meteorol., 103, 279-300, 2000.
Van Breemen, N. and Van Dijk, H. F. G.: Ecosystem effects of atmospheric deposition of nitrogen in The Netherlands, Environ. Pollut., 54, 249-274, 1988.

Van der Hoek, K. W.: Estimating ammonia emission factors in Europe: summary of the work of the UNECE ammonia expert panel, Atmos. Environ., 32, 315-316, 1998.

Van Hove, L. W. A., Koops, A. J., Adema, E. H., Vredenberg, W. J., and Pieters, G. A.: A study of the adsorption of $\mathrm{NH}_{3}$ and $\mathrm{SO}_{2}$ on leaf surfaces, Atmos. Environ., 23, 1479-1486, 1989.

Varlet-Grancher, C., Gosse, G., Chartier, M., Sinoquet, H., Bonhomme, R., and Allirand, J.-M.: Mise au point : rayonnement solaire absorbé ou intercepté par un couvert végétal, Agronomie, 9, 419-439, 1989.

Wesely, M. L.: Parameterization of surface resistances to gaseous dry deposition in regional-scale numerical models Atmos. Environ., 23, 1293-1304, 1989.

Weyers, J. D. B. and Meidner, H.: Methods in stomatal research, Longman Scientific and Technical ed., 1990.

Zhang, Y., Wu, S.-Y, Krishnan, S., Wang, K., Queen, A., Aneja, V. P., and Arya, S. P.: Modeling agricultural air quality: Current status, major challenges, and outlook, Atmos. Environ., 42, 3218-3237, 2008.

Zhou, M. C., Ishidaira, H., Hapuarachchi, H. P., Magome, J., Kiem, A. S., and Takeuchi, K.: Estimating potential evapotranspiration using Shuttelworth-Wallace model and NOAA-AVHRR NDVI data to feed a ditributed hydrological model over the Mekong River basin, J. Hydrol., 327, 151-173, 2006. 